\title{
Carbon-13 in groundwater from English and Norwegian crystalline rock aquifers: a tool for deducing the origin of alkalinity?
}

\author{
Simon Bottrell ${ }^{1}$ Emma V. Hipkins ${ }^{1,2} \cdot$ James M. Lane $^{1} \cdot$ Rose A. Zegos $^{1} \cdot$ \\ David Banks $^{3,4}$ (i) Bjørn S. Frengstad ${ }^{5}$
}

Received: 28 May 2016 / Accepted: 20 October 2017 / Published online: 2 November 2017

(C) The Author(s) 2017. This article is an open access publication

\begin{abstract}
The ${ }^{13} \mathrm{C}$ signature is evaluated for various environmental compartments (vegetation, soils, soil gas, rock and groundwater) for three crystalline rock terrains in England and Norway. The data are used to evaluate the extent to which stable carbon isotopic data can be applied to deduce whether the alkalinity in crystalline bedrock groundwaters has its origin in hydrolysis of carbonate or silicate minerals by $\mathrm{CO}_{2}$. The resolution of this issue has profound implications for the role of weathering of crystalline rocks as a global sink for $\mathrm{CO}_{2}$. In the investigated English terrain (Isles of Scilly), groundwaters are hydrochemically immature and DIC is predominantly in the form of carbonic acid with a soil gas signature. In the Norwegian terrains, the evidence is not conclusive but is consistent with a significant fraction of the groundwater DIC being derived from silicate hydrolysis
\end{abstract}

This article is part of the special issue on Sustainable Resource Management: Water Practice Issues.

Electronic supplementary material The online version of this article (doi:10.1007/s40899-017-0203-7) contains supplementary material, which is available to authorized users.

David Banks

david@holymoor.co.uk

1 School of Earth and Environment, University of Leeds, Leeds LS2 9JT, UK

2 School of Geosciences, University of Edinburgh, The King's Buildings, James Hutton Road, Edinburgh EH9 3FE, UK

3 School of Engineering, University of Glasgow, James Watt Building (South), Glasgow G12 8QQ, UK

4 Holymoor Consultancy Ltd., 360 Ashgate Road, Chesterfield S40 4BW, UK

5 Department of Geoscience and Petroleum, Norwegian University of Science and Technology, 7491 Trondheim, Norway by $\mathrm{CO}_{2}$. A combined consideration of $\mathrm{pH}$, alkalinity and carbon isotope data, plotted alongside theoretical evolutionary pathways on bivariate diagrams, strongly suggests real evolutionary pathways are likely to be hybrid, potentially involving both open and closed $\mathrm{CO}_{2}$ conditions.

Keywords $\mathrm{CO}_{2}$ sink $\cdot$ Carbonate $\cdot$ Silicate $\cdot{ }^{13} \mathrm{C}$ isotope . Groundwater $\cdot$ Granite

\section{Introduction}

Hydrogeochemistry, alkalinity and the global $\mathrm{CO}_{2} \operatorname{sink}$

Relatively little recent discussion has taken place in the scientific literature regarding the evolution of carbonate alkalinity in groundwater in crystalline silicate bedrock aquifers, such as granites, gneisses, basalts, dolerites, and schists. Despite the relatively low yields obtained from most such aquifers (Banks et al. 2010), they often form an important component of rural potable water supply in areas underlain by ancient shield terrane (Fennoscandian shield, Canadian shield, African shield) and the cores of orogenic belts (the Caledonides of Norway, Sweden and Scotland, the Hercynides of SW Britain and the Alps).

The accumulation of alkalinity in groundwater in such aquifers is intimately linked to the evolution of $\mathrm{pH}$, a master variable which often controls the solubility of other trace elements that may have health-related significance (Frengstad et al. 2001; Appelo and Postma 2005).

Additionally, however, the enrichment of alkalinity in groundwater is an indicator of the consumption of carbon dioxide in mineral weathering and, thus, offers insights into the magnitude of the global sink for atmospheric carbon that mineral weathering represents. Several authors (e.g. Banks 
and Frengstad 2006; Schulte et al. 2011) have suggested that ${ }^{13} \mathrm{C}$ stable isotope determinations might ("Implications for bedrock weathering as a global CO2 sink", "Carbon isotope fractionation in the groundwater recharge process", "Hypothetical groundwater 13C signatures in carbonate and silicate weathering systems") be able to indicate whether this alkalinity is derived from silicate or carbonate weathering and, thus, whether it represents a permanent or temporary $\mathrm{CO}_{2}$ sink. This paper presents data on ${ }^{13} \mathrm{C}$ in several different environmental "compartments" (vegetation, soil gas, soils and groundwater) from three different English and Norwegian crystalline bedrock areas. It uses the data to ascertain whether this hypothesis can be readily applied in practice to ascertain if groundwater alkalinity is derived primarily from carbonate weathering (temporary $\mathrm{CO}_{2}$ sink) or silicate weathering (permanent $\mathrm{CO}_{2}$ sink).

\section{Hydrogeochemical evolution in crystalline bedrock aquifers}

A typical evolution of groundwaters in crystalline bedrock aquifers in boreal and temperate climates appears to follow a pathway comprising four broad 'phases' (Frengstad and Banks 2007):

Phase (i) Hydrochemically immature waters. Low $\mathrm{pH}$ and alkalinity, cationic and anionic composition still characterized by evapo-concentrated components of rainfall.

Phase (ii) Gradual enrichment of base cations and alkalinity in groundwater, typically calcium and bicarbonate. Circum-neutral $\mathrm{pH}$.

Phase (iii) Preference for accumulation of sodium and bicarbonate. As $\mathrm{pH}$ increases to alkaline values, apparent depletion of calcium to leave a high-pH sodium bicarbonate water.

Phase (iv) At greater depth and prolonged residence time, deep brines (Gascoyne and Kamineni 1993; Bottomley et al. 1990) of sodium/calcium sulphate/chloride composition.

Banks and Frengstad (2006) noted that water types representing Phases (i) to (iii) could be found in shallow Norwegian crystalline bedrock aquifers, even in relatively simple aquifer lithologies such as anorthosite (Table 1), which is dominated by plagioclase feldspar. It seems reasonable that groundwaters in Phase (i) represent newly recharged water, with very little rock-water interaction and containing evapo-concentrated rainfall solutes. The evolution to Phase (ii) represents the accumulation of base cations (especially calcium and bicarbonate) by the relatively rapid hydrolysis of carbonate minerals, such as calcite (Eq. 1a), and, to some extent, kinetically slower hydrolysis of silicate minerals. Calcite and other carbonates may be present in soils or recent superficial deposits overlying the crystalline bedrock aquifer, or they may be present as trace components
Table 1 Three characteristic groundwater analyses from the Egersund anorthosite massif, Norway, ranging from Phase (i) evapoconcentrated recharge water, dominated by $\mathrm{Na}$ and $\mathrm{Cl}$ from rainfall recharge, to Phase (iii) high $\mathrm{pH}, \mathrm{Na}-\mathrm{HCO}_{3}$ water, depleted in calcium. Data from Banks and Frengstad (2006)

\begin{tabular}{lllll}
\hline Sample & & 2 & 5 & 8 \\
\hline Phase & & $(\mathrm{i})$ & (ii) & (iii) \\
$\mathrm{Eh}$ & $\mathrm{mV}$ & +260 & +171 & +70 \\
$\mathrm{pH}$ & & 5.59 & 7.90 & 9.72 \\
Alkalinity & $\mathrm{meq} / \mathrm{L}$ & 0.2 & 2.2 & 3.0 \\
$\mathrm{Na}^{+}$ & $\mathrm{mg} / \mathrm{L}$ & 20.5 & 40.7 & 83.2 \\
$\mathrm{Ca}^{2+}$ & $\mathrm{mg} / \mathrm{L}$ & 7.86 & 40.9 & 2.49 \\
$\mathrm{Mg}^{2+}$ & $\mathrm{mg} / \mathrm{L}$ & 4.02 & 16.3 & 0.97 \\
$\mathrm{~K}^{+}$ & $\mathrm{mg} / \mathrm{L}$ & 2.16 & 3.11 & 0.63 \\
$\mathrm{Cl}^{-}$ & $\mathrm{mg} / \mathrm{L}$ & 34.2 & 18.1 & 30.9 \\
$\mathrm{SO}_{4}{ }^{2-}$ & $\mathrm{mg} / \mathrm{L}$ & 13.9 & 33.9 & 12.1 \\
$\mathrm{NO}_{3}{ }^{-}$ & $\mathrm{mg} / \mathrm{L}$ & 12.5 & 127 & $<0.05$ \\
$\mathrm{~F}^{-}$ & $\mathrm{mg} / \mathrm{L}$ & $<0.05$ & 0.06 & 0.07 \\
$\mathrm{Si}^{2}$ & $\mathrm{mg} / \mathrm{L}$ & 2.06 & 3.41 & 4.16 \\
\hline
\end{tabular}

or fracture surface minerals within the crystalline bedrock lithology itself (White et al. 1999, 2005).

$\mathrm{H}_{2} \mathrm{O}+\mathrm{CO}_{2}+\mathrm{CaCO}_{3}=\mathrm{Ca}^{2+}+2 \mathrm{HCO}_{3}^{-}$

Many hydrogeologists explain the transition from Phase (ii) to Phase (iii) by ion exchange of sodium for calcium. The removal of calcium also increases calcite undersaturation and, thus, potentially allows the further dissolution of calcium carbonate and accumulation of alkalinity (Eq. 1b; Model A).

$\mathrm{Ca}^{2+}+2 \mathrm{HCO}_{3}{ }^{-}+\mathrm{IEM}_{-} \mathrm{Na}_{2}=2 \mathrm{Na}^{+}+2 \mathrm{HCO}_{3}{ }^{-}+\mathrm{IEM}-\mathrm{Ca}$

where IEM is an ion exchange medium (e.g. a clay).

Frengstad and Banks (2000) and Banks and Frengstad (2006) posited the alternative explanation (Model B) that Phase (iii) represents the gradual predominance of kinetically slower hydrolysis of abundant silicate (e.g. plagioclase feldspar) phases by dissolved carbon dioxide (Eq. 2).

$$
\begin{aligned}
2 \mathrm{NaCaAl}_{3} \mathrm{Si}_{5} \mathrm{O}_{16} & +6 \mathrm{CO}_{2}+9 \mathrm{H}_{2} \mathrm{O}=2 \mathrm{Ca}^{2+}+2 \mathrm{Na}^{+} \\
+ & 6 \mathrm{HCO}_{3}{ }^{-}+4 \mathrm{SiO}_{2}+3 \mathrm{Al}_{2} \mathrm{Si}_{2} \mathrm{O}_{5}(\mathrm{OH})_{4}
\end{aligned}
$$

Banks and Frengstad (2006) explained the depletion in calcium and evolution of groundwaters to very high $\mathrm{pH}$ values by the progressive precipitation of calcite as alkalinity accumulates from silicate hydrolysis (Eq. 3).

$$
\begin{aligned}
2 \mathrm{NaCaAl}_{3} \mathrm{Si}_{5} \mathrm{O}_{16} & +4 \mathrm{CO}_{2}+7 \mathrm{H}_{2} \mathrm{O}=2 \mathrm{CaCO}_{3}+2 \mathrm{Na}^{+} \\
+ & 2 \mathrm{HCO}_{3}^{-}+4 \mathrm{SiO}_{2}+3 \mathrm{Al}_{2} \mathrm{Si}_{2} \mathrm{O}_{5}(\mathrm{OH})_{4}
\end{aligned}
$$


Frengstad and Banks (2007), while recognising that carbonate dissolution and ion exchange may be important processes in many specific cases, argued that silicate (often dominated by feldspar) hydrolysis alone can explain most of the main hydrochemical trends observed in groundwaters from silicate crystalline rocks. They contended [by merely extending the evolutionary principles first proposed by Garrels (1967) and Garrels and MacKenzie (1967)] that these trends are not strongly dependent on lithology, but are dependent on five more universal factors; (1) the initial partial pressure of $\mathrm{CO}_{2}\left(\mathrm{PCO}_{2}\right)$ of the recharge water, (2) the degree to which the aquifer geochemical system is "open" or "closed" with respect to $\mathrm{CO}_{2}$, (3) the availability and composition of hydrolysable silicate phases, (4) the degree to which $\mathrm{CO}_{2}$ has been consumed by silicate (e.g. plagioclase) hydrolysis and (5) the extent to which silicate hydrolysis has continued beyond the point of calcite saturation.

\section{Implications for bedrock weathering as a global $\mathrm{CO}_{2}$ sink}

In the context of greenhouse gas-coupled climate change it is important to understand and quantify the various available $\mathrm{CO}_{2}$ sources and sinks globally. One, often under-recognized, potential sink is the consumption of $\mathrm{CO}_{2}$ by weathering of carbonate, aluminosilicate and other basic minerals in the subsurface (Brady 1991; Liu and Zhao 2000; Probst et al. 1998; Gaillardet et al. 1999; Amiotte-Suchet et al. 2003; Beaulieu et al. 2012). Especially in the boreal regions of the globe, the terrain is underlain by large areas of glaciated shield terrain where relatively fresh crystalline bedrock mineral assemblages have been recently exposed (Canada, Fennoscandia, Greenland, parts of Russia and Siberia).

Note that, in Model A, the groundwater's alkalinity is derived from carbonate hydrolysis, in which case, half of the resultant alkalinity in groundwater is derived from mineralogical fixation of atmospheric/soil-produced $\mathrm{CO}_{2}$ (Eqs. 1a, b).

In Model B, the alkalinity is derived from silicate hydrolysis, in which case, all the resultant alkalinity in groundwater is derived from mineralogical fixation of atmospheric/ soil-produced $\mathrm{CO}_{2}$ (Eqs. 2, 3). This has obvious implications for scientists attempting to quantify the degree to which mineral weathering acts as a global sink for $\mathrm{CO}_{2}$. Of course, if the groundwater discharges to a surface or ocean water, calcite may be precipitated, re-releasing $\mathrm{CO}_{2}$ :

$\mathrm{Ca}^{2+}+2 \mathrm{HCO}_{3}^{-}=\mathrm{H}_{2} \mathrm{O}+\mathrm{CO}_{2}+\mathrm{CaCO}_{3}$.

If this is taken into account, the net mineralogical fixation of $\mathrm{CO}_{2}$ in Model A might be as low as zero, while in Model $\mathrm{B}$ it would be no lower than $50 \%$.
The methods, based on ${ }^{13} \mathrm{C}$ characterisation of groundwater dissolved inorganic carbon (DIC), described in this paper potentially allow us to distinguish between the two models for groundwater alkalinity generation and, hence, to refine our estimates of the magnitude of the mineralogical $\mathrm{CO}_{2}$ sink.

\section{Carbon isotope fractionation in the groundwater recharge process}

Atmospheric carbon dioxide has a typical $\delta^{13} \mathrm{C}$ of -6 to - 8\%o (Cerling et al. 1991; see also Craig 1953). As this carbon is photosynthesized by plants and incorporated into plant tissue, it undergoes a fractionation, depending on the metabolic pathways of the plant in question. C3 metabolic pathways (including most temperate plant species) result in a $\delta^{13} \mathrm{C}$ composition in the range -20 to $-40 \%$ o (Staddon 2004), but most typically -24 to $-30 \%$ (Clark and Fritz 1997).

As plant material decays and soil is formed, this signature is broadly preserved, with a bulk soil organic $\delta^{13} \mathrm{C}$ of -23 to $-30 \%$ being typical for temperate climates. The biota living in such soils generally exhibit $a+1-2 \%$ o differential relative to the bulk soil.

Plant roots and some soil biota respire $\mathrm{CO}_{2}$, while other soil organisms degrade soil organic matter by heterotrophic microbial oxidation (Gillon et al. 2012). Root-respired $\mathrm{CO}_{2}$ is similar to the bulk plant root $\delta^{13} \mathrm{C}$ composition, while degradation-derived $\mathrm{CO}_{2}$ is typically slightly depleted in ${ }^{13} \mathrm{C}$. The "biologically-produced soil $\mathrm{CO}_{2}$ " thus has a $\delta^{13} \mathrm{C}$ signature slightly lower than the plants and the bulk soil, at around -32 to $-27 \%$.

This "biologically-produced soil $\mathrm{CO}_{2}$ ", however, is not necessarily identical to the bulk soil gas $\mathrm{CO}_{2}$ signature, the latter being affected by diffusion of soil $\mathrm{CO}_{2}$. As isotopically lighter ${ }^{12} \mathrm{CO}_{2}$ diffuses faster, the soil gas $\delta^{13} \mathrm{C}$ signature is heavier than that of the "biologically-produced soil $\mathrm{CO}_{2}$ ", and increases upwards in the soil profile, as the soil-atmosphere interface is approached. The higher the soil respiration/degradation rate, the lighter the soil gas $\delta^{13} \mathrm{C}$ signature will be. Irrespective of this rate, at some depth within the soil profile, a steady state $\delta^{13} \mathrm{C}$ signature will be achieved which, in well-drained soils, is normally $+4.4 \%$ o higher (heavier) than the biologically produced signature (Cerling 1984; Cerling et al. 1991, while Dörr and Münnich 1980; Alpers et al. 1990, discuss other factors that may affect this signature). Thus, at depth, a soil gas $\mathrm{CO}_{2}$ signature of -27.5 to $-23 \%$ is typical in temperate regions, dominated by $\mathrm{C} 3$ plants (as is the case for the three study areas). These processes are summarized in Fig. 1. It should be noted that, as biological productivity varies strongly seasonally (being highest in summer; Atkinson 1977, Qi at al. 2002), one 


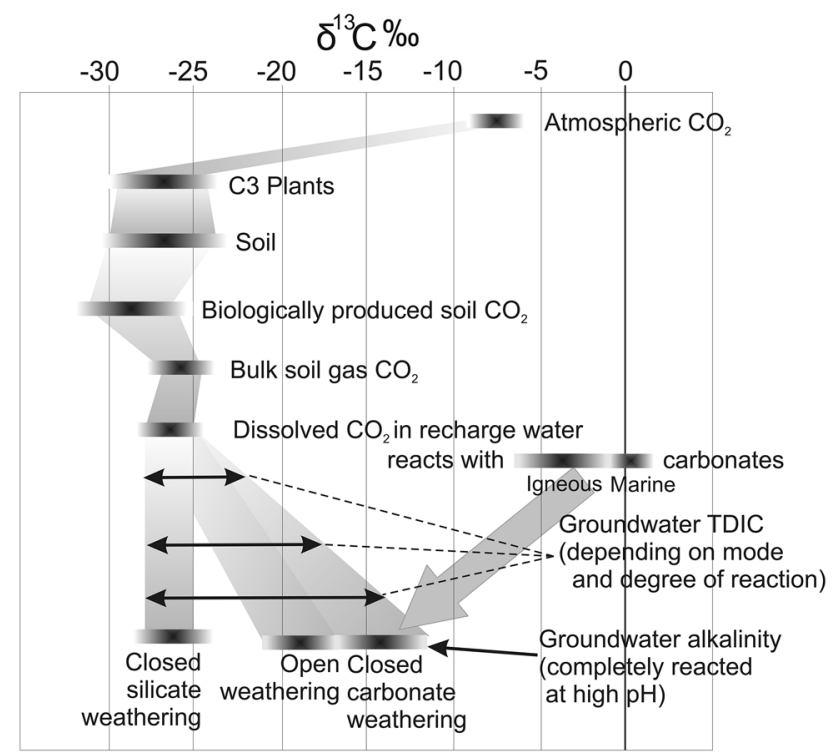

Fig. 1 Diagrammatic idealized representation of evolution of $\delta^{13} \mathrm{C}$ signature in a typical temperate soil/soil gas/groundwater system. Ocean water has a $\delta^{13} \mathrm{C}$ of around $0 \%$. The grey shading shows speculative ranges of isotopic signature, but founded in commonly observed values, as documented in "Carbon isotope fractionation in the groundwater recharge process" and "Hypothetical groundwater 13C signatures in carbonate and silicate weathering systems"

might expect the soil gas $\delta^{13} \mathrm{C}$ signature to also vary with season and with weather/barometric conditions.

The soil gas $\mathrm{CO}_{2}$ dissolves in recharge water (with a very modest associated $\delta^{13} \mathrm{C}$ fractionation of c. $-1 \%$ - Szaran 1998; Clark and Fritz 1997) and, either in the unsaturated or saturated zone, may react with basic mineral phases (carbonates or silicates etc.), resulting in a $\mathrm{pH}$ rise and an accumulation of bicarbonate or carbonate ions and base cations in the water [see Model A (Eqs. 1a, b) and Model B (Eq. 2)].

The equilibrium transition from dissolved $\mathrm{CO}_{2(\mathrm{aq})}$ to $\mathrm{HCO}_{3}{ }^{-}$is associated with a rather strong $\delta^{13} \mathrm{C}$ fractionation of +10 to $+11 \%$ o (Mook et al. 1974; Clark and Fritz 1977). The further equilibrium transition to $\mathrm{CO}_{3}{ }^{2}$ is associated with a further fractionation of -0.4 to $-0.6 \%$. If the groundwater becomes saturated with respect to calcite and some degree of calcite precipitation occurs (Eq. 3), a further modest $(<2 \%)$ fractionation may be observed
(Emrich et al. 1970). Thus, in an equilibrated (open with respect to an effectively unlimited reservoir of $\mathrm{CO}_{2}$ ) system, characterised by a soil gas of $\delta^{13} \mathrm{C}=-26 \%$, one would expect the ${ }^{13} \mathrm{C}$ signatures presented in Table 2.

\section{Hypothetical groundwater ${ }^{13} \mathrm{C}$ signatures in carbonate and silicate weathering systems}

In a purely silicate weathering system (Model B, above), the hydrolysis of silicate minerals raises the groundwater $\mathrm{pH}$, converting dissolved $\mathrm{CO}_{2(\mathrm{aq})}$ to $\mathrm{HCO}_{3}{ }^{-}$and, at higher $\mathrm{pH}$, to $\mathrm{CO}_{3}=$.

In a closed silicate weathering system, where the mineral assemblage has access to an initial finite dissolved $\mathrm{CO}_{2}$ content, the overall $\delta^{13} \mathrm{C}$ of the groundwater dissolved inorganic carbon (DIC) remains unchanged at the initial $\delta^{13} \mathrm{CO}_{2(\mathrm{aq})}$ value. As weathering progresses, the distribution of the species $\left(\mathrm{CO}_{2(\mathrm{aq})}, \mathrm{HCO}_{3}{ }^{-}\right.$and $\left.\mathrm{CO}_{3}{ }^{-}\right)$comprising the DIC will shift to the right, but the total DIC will remain constant (at least, until saturation with respect to a carbonate mineral occurs, at which point a small fractionation may take place on precipitation-Emrich et al. 1970).

In an open silicate weathering system, the groundwater constantly has access to an unlimited supply of soil gas carbon dioxide to replace that converted to bicarbonate by mineral hydrolysis and $\mathrm{pH}$ increase. At any given point, the speciation of DIC will depend solely on $\mathrm{pH}$ and can be calculated. By assigning values of $\delta^{13} \mathrm{C}$ to each species (as in Table 2, for example), the total $\delta^{13} \mathrm{C}$ of the DIC can be calculated. As $\mathrm{pH}$ rises and a greater proportion of the DIC is in the form of $\mathrm{HCO}_{3}{ }^{-}$or $\mathrm{CO}_{3}{ }^{=}$, the $\delta^{13} \mathrm{C}$ of the DIC becomes isotopically heavier.

In a carbonate weathering system (Model $\mathrm{A}$ ), one might expect the soil gas-derived $\mathrm{CO}_{2}$ (highly negative $\delta^{13} \mathrm{C}$ ) to be "diluted" by dissolution of aquifer carbonate (which typically has a $\delta^{13} \mathrm{C}$ close to $0 \%$, if marine-derived). In a closed carbonate weathering system, this is indeed the case and, once the finite quantity of dissolved soil-derived $\mathrm{CO}_{2}$ has fully reacted with aquifer carbonate, an intermediate $\delta^{13} \mathrm{C}$ should result (Schulte et al. 2011-see Equations 1). For example, if the dissolved soil-derived $\mathrm{CO}_{2}$ has a $\delta^{13} \mathrm{C}=-26 \%$, one would expect the DIC $\delta^{13} \mathrm{C}$ to tend towards $-13 \%$.

Table 2 Fractionation, at $10{ }^{\circ} \mathrm{C}$, of $\delta^{13} \mathrm{C}$ signature in the aqueous carbonate system in equilibrium with an effectively unlimited gaseous carbon dioxide reservoir of signature $\delta^{13} \mathrm{C}=-26 \%$ (i.e. open system). (Values from Clark and Fritz 1977)

\begin{tabular}{|c|c|c|c|c|c|c|c|}
\hline & $\mathrm{CO}_{2 \text { (gas) }}$ & $\leftrightarrow$ & $\mathrm{CO}_{2(\mathrm{aq})}$ & $\leftrightarrow$ & $\mathrm{HCO}_{3}^{-}{ }_{(\mathrm{aq})}$ & $\leftrightarrow$ & $\mathrm{CO}_{3}{ }^{2-}$ (aq) \\
\hline Fractionation & & $-1.1 \%$ & & $+10.7 \%$ & & $-0.4 \% o$ & \\
\hline $\begin{array}{l}\text { Total fractionation from } \\
\mathrm{CO}_{2 \text { (gas) }}\end{array}$ & & & $-1.1 \%$ & & $+9.6 \%$ & & $+9.2 \%$ \\
\hline Signature & $-26 \%$ & & $-27.1 \%$ & & $-16.4 \%$ o & & $-16.8 \%$ o \\
\hline
\end{tabular}




$$
\begin{gathered}
\mathrm{CaCO}_{3}\left(\delta^{13} \mathrm{C}=0 \% \text { \%o }\right)+\mathrm{CO}_{2(\mathrm{aq})}\left(\delta^{13} \mathrm{C}=-26 \% \circ\right) \\
+\mathrm{H}_{2} \mathrm{O}=\mathrm{Ca}^{++}+2 \mathrm{HCO}_{3}^{-}\left(\delta^{13} \mathrm{C}=-13 \% \circ 0\right)
\end{gathered}
$$

In a truly open carbonate weathering system, the speciation of DIC and its $\delta^{13} \mathrm{C}$ depend only on $\mathrm{pH}$. Thus, in an idealised open system, the evolution of the $\delta^{13} \mathrm{C}$ of DIC is the same as for silicate weathering and the "isotopic composition of the dissolved carbonate rock does not influence the ${ }^{13} \mathrm{C} /{ }^{12} \mathrm{C}$ ratio of the carbonate in solution" (Deines et al. 1974). In reality, of course, isotopic exchange between the dissolved and gaseous species may not be perfect nor instantaneous and a given $\mathrm{CO}_{2}$ system may be in some way "intermediate" between the idealised open and closed situations.

The suggestion made by authors such as Banks and Frengstad (2006) and Schulte et al. (2011) —namely that ${ }^{13} \mathrm{C}$ isotopic signatures could potentially be used to distinguish between silicate and carbonate weathering (Models A and B) - is potentially a powerful one. However, although it would appear that $\delta^{13} \mathrm{C}$ could be used to distinguish closed system silicate and carbonate weathering, there is no clear isotopic distinction between purely (ideal) open $\mathrm{CO}_{2}$ weathering pathways.

To attempt to ascertain the practical utility (if any) of ${ }^{13} \mathrm{C}$ in resolving such issues, samples of vegetation, soils, soil gas and groundwater DIC were collected from three different crystalline bedrock terrains: the granitic Scilly Isles of south-west England, the Iddefjord granite of south-east Norway and the Egersund anorthosite complex of south-west Norway. The last-named terrain is specially selected, as it comprises a simple mineralogy (dominated by plagioclase feldspar) with very little superficial cover, thus potentially minimising the impacts of carbonate mineral weathering in either the bedrock or overburden.

\section{The study areas}

\section{Egersund anorthosite complex, Rogaland County, Norway}

Egersund is situated in the county of Rogaland, southeast of Stavanger on the south-western coast of Norway (Fig. 2). The sampled area is underlain by the Precambrian Egersund-Ogna anorthosite massif which was emplaced into the Sweconorwegian orogenic belt at $931 \pm 3 \mathrm{Ma}$ (Schärer et al. 1996). The anorthosite typically comprises $90 \%$ coarsegrained plagioclase crystals (An40-50), with subsidiary Alorthopyroxene, the whole being intruded by dolerite dykes (Ashwal 1993).

The terrain is dominated by extensive freshly glacially scoured and striated bedrock exposure. In coastal areas and below the level of the postglacial upper marine limit (PGUML), marine silts and clays (whose pore water
Fig. 2 Map of north-western Europe, showing the locations of the three study areas as red circles (Scilly, Egersund and Hvaler-Iddefjord). Also shows named rainfall stations as blue stars

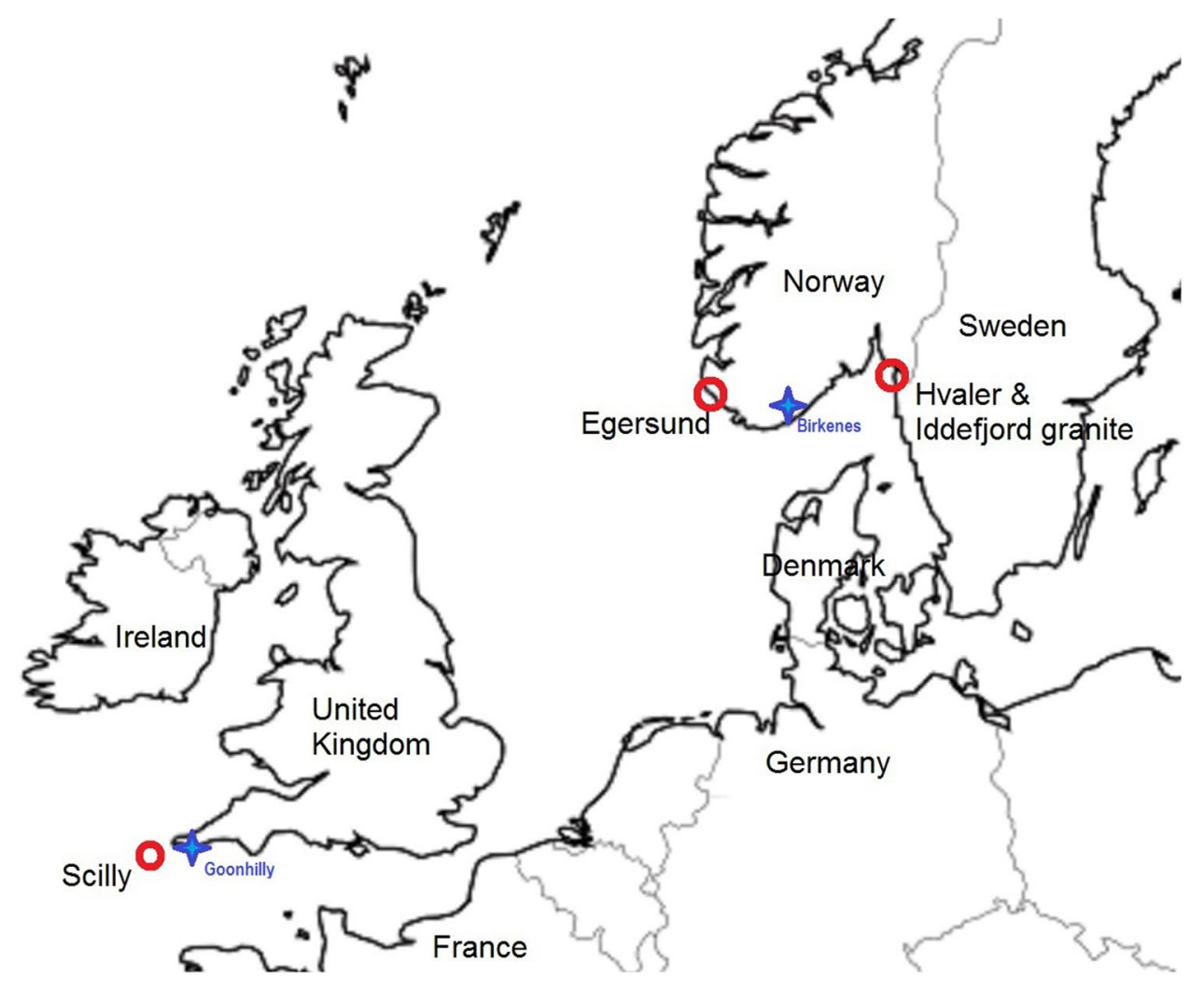


provides a potential source of marine salts to groundwater) occur in lower-lying terrain. These may be overlain in valleys by glaciofluvial and alluvial sands and gravels, which also occur in limited valley deposits above the PGUML. Postglacial isostatic uplift is of the order of $15 \mathrm{~m}$ (Norges geologiske unders $\emptyset$ kelse 2014). Topography inland is relatively steep and soil cover is typically absent or very thin, except in local valley areas or under well-established forest areas. The annual average temperature is slightly over $7{ }^{\circ} \mathrm{C}$ at sea level and the maximum tidal range is only some $0.5 \mathrm{~m}$. The annual precipitation is around $1540 \mathrm{~mm}$ (1971-2000; Norsk Klimaservicesenter 2017a). The potential evapotranspiration is around $450 \mathrm{~mm}$ (HydroTeamRC 2015).

The area is within the Boreal belt (Sundseth 2009), dominated by $\mathrm{C} 3$ processing plant pathways, an important control on the isotopic composition of the stable carbon contained within soil gas $\mathrm{CO}_{2}$. Banks and Frengstad (2006) recorded $\mathrm{CO}_{2}$ concentrations of 1-3.4 vol.\% $\left(\mathrm{PCO}_{2}\right.$ $10^{-1.47}$ to $10^{-2} \mathrm{~atm}$.) in soil gas in the Egersund anorthosite area. Vegetation consists of scrub and low trees, including aspen, bilberry, birch, spruce, juniper, oak, pine, grasses and mosses.

\section{The Hvaler Islands and surrounding area: Iddefjord Granite, Østfold County, Norway}

The Iddefjord Granite outcrops in the southern region of Østfold County, Norway. It continues across the Swedish border, where it is referred to as the Bohus Granite. As well as the mainland areas around Fredrikstad and Halden, the granite also forms the popular holiday archipelago of the Hvaler Islands. The Iddefjord Granite of Hvaler is arguably one of the most-studied bedrock aquifers of Norway (Banks et al. 1992a, b, 1993a, b, 1994). The islands are an emergent landscape, having been exposed from the Skagerrak by postglacial isostatic uplift during the past 10,000 years. The islands have some pastoral and arable agricultural activity, but are also characterised by many holidaymakers' cottages.

According to Oxaal (1916), the Iddefjord Granite derives from the end of the Sveconorwegian orogeny $(981 \pm 7 \mathrm{Ma})$ and comprises 13 magmatic intrusions ranging from diorite to granite in composition, intruded into Precambrian gneiss country rocks. The granites are characterised as 'S type' (sedimentary origin) and are typically medium grained with c. $71-75 \% \mathrm{SiO}_{2}$ content and composed of quartz, microcline and plagioclase with accessory biotite, hornblende, muscovite, iron oxides, chlorite, apatite, titanite and zircon. The granite was subsequently intruded by dolerite dykes, some of which are deeply eroded and glacially "plucked". Many granite fractures are filled with smectite mineralization (Kocheise 1994), and other observed fracture minerals include chlorite, fluorite, epidote and calcite. Some of this mineralization may be related to Permian hydrothermal activity associated with the Oslo Rift (Oxaal 1916; Holtedahl 1960; Pedersen and Maaløe 1990; Banks et al. 1993b, 1994, 1997).

The terrain is dominated by extensive freshly glacially scoured and striated bedrock exposure. In coastal areas and below the level of the PGUML (which is at around $170 \mathrm{~m}$ asl-Selmer-Olsen 1964), marine silts and clays occur. Especially in the low-lying Hvaler islands, extensive deposits of shallow marine and littoral silts and sands are observed. Quaternary sedimentation also occurs within the eroded fracture zones of the granite terrain. A major terminal moraine train from the last deglaciation of Oslofjord can also be found. The annual average temperature is over $7{ }^{\circ} \mathrm{C}$ at sea level and the maximum tidal range is only some $0.5 \mathrm{~m}$.

The location is within the Boreal C3 belt. Vegetation consists of scrub and trees, including aspen, bilberry, birch, hazel, heather, juniper, oak, pine, rowan, sallow, spruce, umbellifers, grasses and mosses. Despite its extensive fresh granite surface exposure, large areas of low-lying Hvaler have a thin cover of Quaternary marine drift including some shell sand, well-developed vegetation and a consequent thick acidic organic soil layer. The annual precipitation is around 755 mm (1971-2000; Norsk Klimaservicesenter 2017b). The potential evapotranspiration is around $600 \mathrm{~mm}$, of which around half is actual evapotranspiration (HydroTeamRC 2015; SMHI 2017).

\section{The Scilly Isles, Cornwall, UK}

The Scilly Isles are a granite archipelago in the Atlantic Ocean some $45 \mathrm{~km}$ WSW from Lands End, Cornwall (Barrow and Flett 1906). The islands form an extension of the Permo-Carboniferous (300 - $275 \mathrm{Ma}$ ) Cornubian Batholith of SW England (Osman 1928; Chen et al. 1993), comprising 'S-type' granitic intrusions, associated with the end of the Variscan orogeny. The granites are peraluminous with a low $\mathrm{Na} / \mathrm{K}$ ratio, and enriched in $\mathrm{Li}, \mathrm{B}$ and $\mathrm{U}$. Two separate intrusions can be recognised in the Scillies, (1) the older coarse-grained Outer Granite forming St Marys, St Martins and much of St Agnes islands (into which the sampled boreholes have been drilled), subsequently intruded by (2) the medium-grained Inner Granite (Jones 1963). The granites comprise quartz, perthitic K-feldspar, oligoclase plagioclase (the feldspars often being porphyritic), lithium-rich biotite and muscovite (Stone and Exley 1989; Banks et al. 1998). Accessory minerals include tourmaline, iron oxides, apatite, zircon, andalusite, rutile, monazite, anastase, topaz, chlorite and brookite.

The Scilly Isles represent a submergent landscape, having formed a larger coherent island mass at the end of the last ice age $(10,000$ years BP). The question of whether (and when) Scilly experienced Pleistocene glaciation 
is still debated, but it seems likely that, during the last glacial maximum, the bulk of the islands were unglaciated, and would have experienced periglacial conditions (Watkins 2000; Mitchell and Orme 1967; Hiemstra et al. 2006). The islands have thus (unlike Hvaler) experienced a geologically long history of sub-aerial weathering. The granite surfaces are seldom fresh and are often covered by a "head" or "ram" (slope-creep) deposit that in many ways resembles a tropical granite weathering layer or regolith. Other superficial deposits are sparse, although limited tracts of clayey alluvium occur in some areas, especially around Old Town on St Marys. Sea level rises (2.1-2.6 $\mathrm{mm} /$ year during the archaeologically datable period) following the last glaciations resulted in the inundation of Scillonia and its separation into the current islands maybe as late as 1000-1500 years BP (Ratcliffe 1992).

The tidal range is high (sometimes exceeding $5.5 \mathrm{~m}$ ), while the annual average temperature is almost $12{ }^{\circ} \mathrm{C}$. The annual average precipitation is $865 \mathrm{~mm}$ (St Mary's Heliport, 1981-2010, Met. Office 2017) while the potential evapotranspiration over well-watered grass is around 526 mm/year (Land's End, 2007-2012, CHESS 2017). The islands host arable and pastoral agriculture and are particularly known for their winter floriculture, due to the mild climate. In recent years, tourism has become dominant as the main source of income. Vegetation includes large expanses of maritime heathland and grassland, with higher ground being occupied by bracken, gorse, heather and rhododendron. Wooded areas (e.g. pine) are scarce, occupying valleys in inland areas of the islands.

\section{Previous comparative study}

Banks et al. (1998) specifically compared the groundwaters of the Hvaler (Iddefjord Granite) and Scilly island groups. They found that the Hvaler groundwaters were typically hydrochemically rather mature (although a significant range was observed), with slightly alkaline $\mathrm{pH}$, high alkalinity and high concentrations of fluoride, radon, uranium and non-marine (lithologically derived) sodium. Concentrations of nitrate were generally low, probably reflecting the lack of winter agriculture on the islands. The Scilly groundwaters, by contrast, were hydrochemically immature, with low $\mathrm{pH}$, alkalinity, fluoride, uranium, radon, calcium and lithologically-derived sodium. Potassium and nitrate were typically rather high, reflecting the leachable nature of the soils and the winter agriculture and floriculture (Fig. 3). Banks et al. (1998) speculated that the differences were due to the most reactive components of the Scilly granite matrix and fracture mineral assemblage having been depleted during the long history of subaerial weathering. At Hvaler, the reactive components of the mineral assemblage are still largely intact, following glacial scouring and marine emergence.

\section{Field methodology}

This paper is based on three studies of carbon isotopes in the vegetation/soil/groundwater system carried out during 2011-2012.

Study 1 Sampling of soil gas, rock and groundwater from the Egersund and Iddefjord granite areas during 27th June to 1 st July 2011.

Study 2 Sampling of soil gas, vegetation, soils, superficial deposits and rock from Egersund and Iddefjord granite areas during 18th to 22nd June 2012.

Study 3 Sampling of soils, rocks, plants, soil gas and groundwater from the Scilly Isles during 18 th to 22 nd September 2012.

\section{Groundwater samples}

Sampled wells and boreholes were typically private sources in regular use and were, therefore, pumped regularly. There was thus generally little need to purge the wells prior to sampling. Samples were typically taken after allowing the sampling tap to run for several minutes. At each site, field determinations were made of $\mathrm{pH}$ (using an appropriately calibrated $\mathrm{pH}$ electrode) and total alkalinity, by means of a Hach digital titrator, using $1.6 \mathrm{~N} \mathrm{H}_{2} \mathrm{SO}_{4}$ and an indicator of end-point $\mathrm{pH}$ c.4.5. Groundwater samples were collected only in the course of studies 1 and 3; the following sample aliquots were collected in polyethylene (PE) bottles:

- $500 \mathrm{~mL}$ aliquot for total dissolved inorganic carbon (TDIC) analysis and $\delta^{13} \mathrm{C}$ determination, to which was added specified quantities of $\mathrm{SrCl}_{2}$ and of $\mathrm{KOH}$ (or, in study $1, \mathrm{NaOH}$ ) in order to precipitate TDIC as $\mathrm{SrCO}_{3}$.

- $500 \mathrm{~mL}$ aliquot, with no reagents added, for $\delta^{34} \mathrm{~S}$ analysis.

- Smaller aliquots (of size 50-100 mL) of groundwater, field filtered at $0.45 \mu \mathrm{m}$, for anion and cation analysis.

\section{Soil gas samples}

Samples of soil gas in Studies 2 and 3 were collected using a hollow steel probe, inserted at a shallow angle to approximately 10-30 cm depth. A manual pump was used to withdraw soil gas, via a system of valves, to helium-grade balloons. The gas was then circulated between the balloons and bubbled through a flask containing a solution of $25 \mathrm{~g}$ $\mathrm{SrCl}_{2}$ and $0.6 \mathrm{~g} \mathrm{KOH}$ in $200 \mathrm{ml}$ deionised water (in Study 

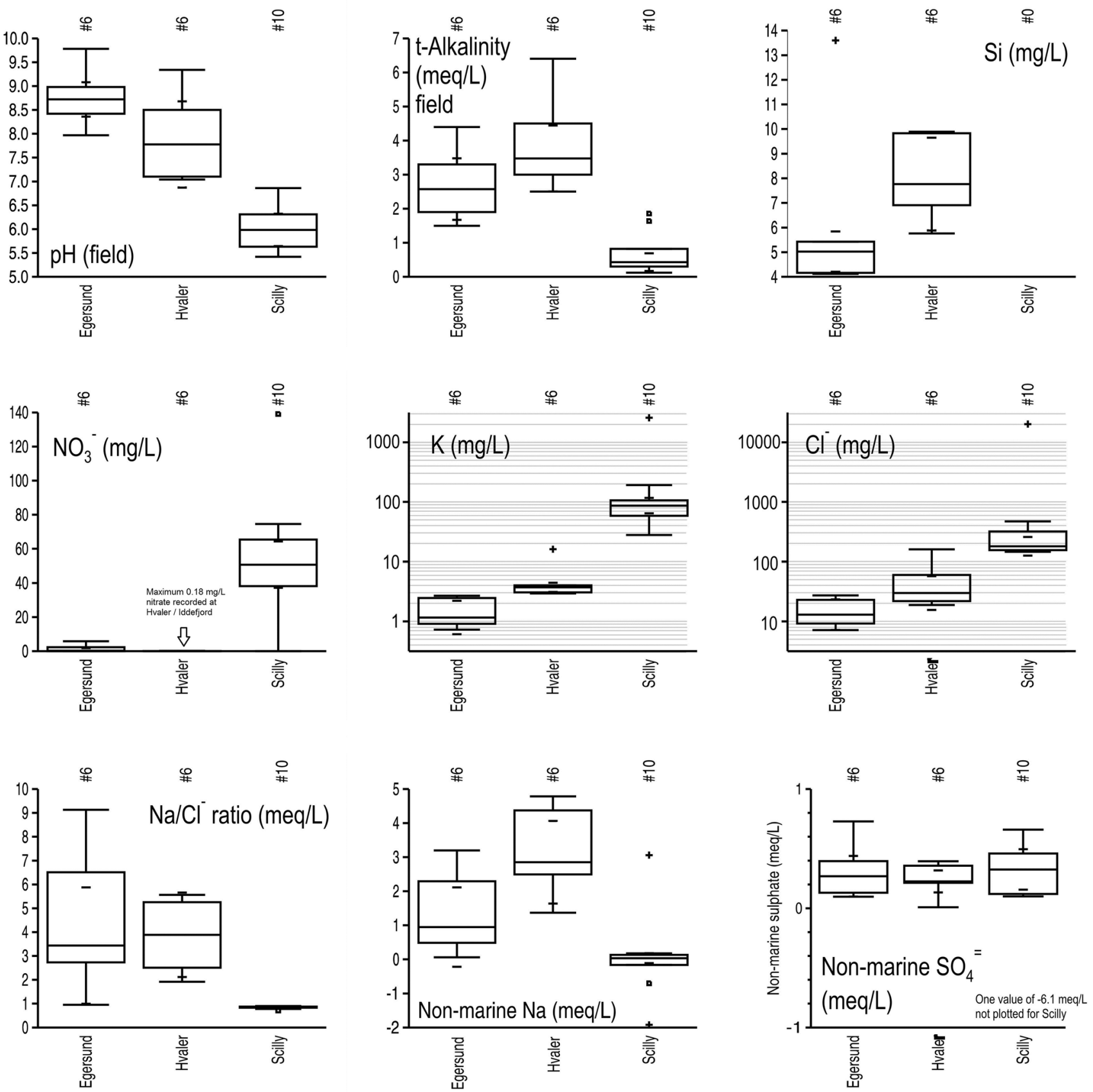

Fig. 3 Boxplots comparing concentrations of various dissolved components in groundwater from the three study areas. In these boxplots, the central box represents the interquartile range (25th-75th percentile), while the central line represents the median, with small horizontal parentheses or "notches" either side the median showing a robust $95 \%$ confidence interval on the median. These allow a graphical test of comparability-much like the formal $t$ test—of the medians via

2, $\mathrm{NaOH}$, rather than $\mathrm{KOH}$ was used). This was repeated at least three times. The soil gas $\mathrm{CO}_{2}$ reacts with the solution and forms a $\mathrm{SrCO}_{3}$ precipitate. In Study 1, a somewhat less sophisticated method was used, involving transport of soil gas back to the laboratory in the UK in gas-tight vessels. notches in the boxplot. The whiskers indicate extraquartile range, with outliers shown as small squares (near outliers) or crosses (far outliers). The \# number above each box represents the sample number in the subset. The maximum recorded nitrate concentration in the Hvaler-Iddefjord data set was only $0.18 \mathrm{mg} / \mathrm{L}$ - thus, the boxplot is not visible on the selected scale

Studies 1 and 2 were carried out in the summer, and study 3 in the autumn: soil gas $\mathrm{CO}_{2}$ content (and by implication, its $\delta^{13} \mathrm{C}$ ) can vary strongly depending on the temperature and season. The soil gas samples collected can thus, at best, only be regarded as representative of the season of sampling 
and not of any annual "average". Moreover, the soil sampling technique (spike) requires a soil profile of several tens of centimetres depth and will thus have been biased against locations within thinner soils. It should be noted that Study 1 was carried out during a particularly wet episode. This may have inadvertently introduced some sample bias towards well-drained soils (low permeability soils being potentially too waterlogged to permit soil gas sampling). Study 2 was carried out in the same geographical areas, but during a period of particularly fine and dry weather, potentially allowing the sampling of a greater range of soil types, including soils from near wetland areas.

\section{Soil samples}

From locations where groundwater or soil gas was sampled, samples of soils were taken (for clarification; the term "soil" refers to organic soils). These were typically taken from 10 to $30 \mathrm{~cm}$ depth. In Study 2, samples were subdivided into deep $(>20 \mathrm{~cm})$ and shallow $(<20 \mathrm{~cm})$ samples. Samples were stored and transported in labelled plastic bags.

In addition, from Hvaler (Study 2) a single sample of marine shell sand, encountered in the shallow subsurface profile at one locality, was also sampled.

\section{Vegetation samples}

From locations where groundwater or soil gas was sampled, samples of living tissue (leaves or needles) of various common vegetation species in the area were taken. The species were identified. Samples were stored and transported in labelled plastic bags.

\section{Rock samples}

Rock samples were typically collected from the outcrops of "freshest" appearance. In Norway, glacial scouring means that many rock outcrops have suffered $<10,000$ years subaerial weathering. In Scilly, weathering is more intense, so the freshest rock exposures were typically from coastal sections.

\section{Laboratory methodology}

For carbon isotope analysis, two types of analytical procedure were typically employed: (1) for inorganic (carbonate) carbon and for (2) organic carbon.

- Groundwater, soil gas, rocks: inorganic carbon
- Plants: organic carbon

- Soils: organic carbon

- Two carbonate-rich soil samples from Scilly: also inorganic carbon

- Marine shell-sand from Hvaler: inorganic carbon

Soil and vegetation samples for organic carbon analysis were treated with $\mathrm{H}_{3} \mathrm{PO}_{4}$ to remove carbonate carbon and then combusted to release the organic carbon as $\mathrm{CO}_{2}$.

For inorganic carbon analysis of groundwater and soil gas samples, inorganic carbon was first immobilized as $\mathrm{SrCO}_{3}$ precipitate (see "Field methodology" above). Inorganic carbon was typically released from the carbonate by hydrolysis with phosphoric acid $\left(\mathrm{H}_{3} \mathrm{PO}_{4}\right)$.

\section{Inorganic carbon isotope analysis}

For groundwater samples, the bottles containing the groundwater and $\mathrm{SrCO}_{3}$ precipitate were weighed and then filtered using a pre-weighed filter and vacuum pump to collect the precipitate, which was thoroughly washed with de-ionized water and dried for $24 \mathrm{~h}$ in an oven $\left(\sim 110^{\circ} \mathrm{C}\right)$. The dry filter papers were then re-weighed to quantify the dry $\mathrm{SrCO}_{3}$ precipitate and (once corrected for purity using the manometric analysis of $\mathrm{C}$ content during preparation for isotopic analysis-see below) hence groundwater TDIC (total dissolved inorganic carbon). A mass of c. 18-20 mg precipitate was reacted with $\mathrm{H}_{3} \mathrm{PO}_{4}$ for 10-15 min. For the precipitates from the soil gas samples from Studies 2 and 3, a similar procedure was followed. In Study $1, \mathrm{CO}_{2}$ from the gas sample vessels was dried and passed directly into the carbon line (see below).

Rock, soil and shell-sand samples were crushed into a fine powder using an agate grinder, and a quantity of 2.5-3.5 g was weighed out and then reacted with $\mathrm{H}_{3} \mathrm{PO}_{4}$ for at least $60 \mathrm{~min}$.

The $\mathrm{CO}_{2}$ released by acid hydrolysis was processed in a purpose-built vacuum line to determine the samples' carbonate content. The gas was passed through a glass coil immersed in a mixture of dry ice and methylated spirit $\left(\sim-80{ }^{\circ} \mathrm{C}\right)$, which removed water vapour by freezing. The residual $\mathrm{CO}_{2}$ gas was then passed into another part of the line, and the $\mathrm{CO}_{2}$ content was frozen out by immersion in liquid $\mathrm{N}_{2}\left(\sim-196^{\circ} \mathrm{C}\right)$, and remaining unwanted gases were pumped away. The frozen $\mathrm{CO}_{2}$ was then allowed to sublime to gas phase in an accurately known volume and the $\mathrm{CO}_{2}$ pressure (yield) was determined using a capacitance manometer. If the $\mathrm{CO}_{2}$ yield was high enough, the pure $\mathrm{CO}_{2}$ gas was passed further down the line where it was again frozen into a valved finger using liquid $\mathrm{N}_{2}$. These glass fingers were then sealed, removed and placed into a SIRA mass spectrometer for $\delta^{13} \mathrm{C}$ analysis. 


\section{Organic carbon isotope and sulphur isotope analysis}

Plant samples were oven-dried and ground using a bladed mill and/or pestle and mortar.

For soil samples, the phosphoric acid/soil mixture resulting from the inorganic carbon extraction (see above) was kept, topped up with deionized water, and left to stand for $24 \mathrm{~h}$, in order for all the inorganic carbon to be released. This was then filtered through a quartz filter paper, dried in an oven for $24 \mathrm{~h}$ at $\sim 110^{\circ} \mathrm{C}$, and ground to a fine powder.

For $\delta^{34} \mathrm{~S}$ analysis of dissolved sulphate in groundwater samples, sufficient $10 \% \mathrm{HCl}$ solution was added to lower the $\mathrm{pH}$ to $2.5-3$. Samples were heated to $\sim 70{ }^{\circ} \mathrm{C}$ and $50 \mathrm{ml}$ of $100 \mathrm{~g} / \mathrm{L} \mathrm{BaCl}_{2}$ solution was added to each sample, and left to stand for at least $24 \mathrm{~h}$, until $\mathrm{a} \mathrm{BaSO}_{4}$ precipitate formed. The precipitate was filtered using pre-weighed filter papers and a vacuum pump, washed, dried, and ground to a fine powder.

In both cases, a very small amount of the oven-dried sample powder $(\sim 0.05-1.00 \mathrm{mg}$ for soils/plants and c. $0.2 \mathrm{mg}$ for groundwater precipitate) was placed into tin cups in a tray alongside other standards, and directly inserted into an Isoprime continuous flow mass spectrometer coupled to an Elementar Pyrocube Elemental Analyser, in order to determine organic carbon and sulphur isotope compositions. Organic carbon and sulphur were quantitatively converted to $\mathrm{CO}_{2}$ and $\mathrm{SO}_{2}$ by combustion at $1150{ }^{\circ} \mathrm{C}$ in the presence of pure oxygen. Water and unwanted gases were scrubbed away before the residual gases were inserted into the mass spectrometer element.

\section{Groundwater chemical analysis}

In Study 1, the groundwater samples were returned to the laboratory of the Geological Survey of Norway and analysed for a range of elements by Inductively Coupled Plasma Atomic Emission Spectroscopy (ICP-AES) using a Perkin Elmer Optima 4300 Dual View instrument and for anions by Dionex DX120 ion chromatography equipment. In Study 3, samples were analysed for major anions and cations using Dionex DX500 and DX600 ion chromatography equipment at the University of Leeds, UK.

\section{Results}

\section{Groundwater chemistry: marine influence}

All three study localities are in a coastal environment. The groundwater contains dissolved sodium (and, for that matter, also magnesium, sulphate etc.) which may in part be derived from (1) direct intrusion of seawater to the groundwater system, (2) pore waters from marine clays and silts or (3) marine salts in rainfall recharge. These ions can also be derived from water-mineral interaction (feldspar hydrolysis, carbonate dissolution or sulphide oxidation) and it can often be important to separate out marine-derived sodium (or $\mathrm{Mg}, \mathrm{SO}_{4}{ }^{\circ}$ ) from lithologically derived (or "non-marine") sodium. This is most conveniently done on the basis of chloride ion concentrations, which are assumed to be wholly derived from marine salts (at least in shallow groundwater systems). Thus:

$\mathrm{Na}_{\mathrm{nm}}=\mathrm{Na}-\left(\mathrm{Cl} \times \mathrm{Na}_{\text {ocean }} / \mathrm{Cl}_{\text {ocean }}\right)$

where $\mathrm{Na}, \mathrm{Cl}$ are the actual sodium and chloride concentrations in groundwater.

$\mathrm{Na}_{\mathrm{nm}}$ is the non-marine (presumed lithologically derived) sodium concentration.

$\mathrm{Na}_{\text {ocean }} / \mathrm{Cl}_{\text {ocean }}$ is the ratio of concentrations in standard ocean water.

In the case of sulphate, an equivalent calculation is applied, although any "non-marine" sulphate component could be ascribed to lithological sources, or to atmospheric contamination of rainfall recharge by industrial emissions. A "non-marine" sulphate deficit, on the other hand, could be construed as removal of sulphate from the groundwater system, e.g. by sulphate reduction.

Figure 3 shows some key aspects of groundwater chemistry from the three study areas, which corroborate findings from previous studies (Banks et al. 1998—see above). Based on chloride concentrations, the Egersund waters exhibit the least marine influence (typically $10-20 \mathrm{mg} / \mathrm{L}$ chloride), then the Hvaler waters (an island group in the Skagerrak, typically $20-60 \mathrm{mg} / \mathrm{L}$ chloride). The greatest marine influence is seen in the groundwaters of the Scilly Isles, in the open Atlantic, with typically over $100 \mathrm{mg} / \mathrm{L}$ chloride. Indeed, Banks et al. (1997) demonstrate that the highest chloride contents in groundwater are found in the western parts of the Scilly archipelago, facing the prevailing westerly winds. The main source of chloride is believed to be marine salts in rainfall, mist and dry deposition of salts subsequently dissolved in rainfall recharge. Eriksson (1952) notes the relationship proposed by Leeflang (1938) for chloride in Dutch rainfall, namely:

$\mathrm{Cl}(\mathrm{mg} / \mathrm{L})=3.0+11.7 \exp (-0.525 x)+3.0 \exp (-0.023 x)$

where $x$ is distance from the coast $(\mathrm{km})$. This implies that, for $x=1 \mathrm{~km}, \mathrm{Cl}^{-}=13 \mathrm{mg} / \mathrm{L}$ and also that marine salt concentrations decrease rapidly within $4 \mathrm{~km}$ of the coast. Reviews by Smith (1872) and Eriksson (1952) noted that average chloride concentrations in rainfall along the Scottish coast were $12-13 \mathrm{mg} / \mathrm{L}$, with over $50 \mathrm{mg} / \mathrm{L}$ being recorded in North Uist on one occasion, while on the west coast of England, over $50 \mathrm{mg} / \mathrm{L}$ was recorded. Banks et al. (1997) recorded $86 \mathrm{mg} / \mathrm{L}$ chloride in a rainwater storage tank in Scilly, whilst Banks et al. (1992b) recorded 42 mg/L 
chloride in storm runoff from granite terrain in Hvaler. The increasing marine influence on surface water chemistry is demonstrated by Banks et al. (2001), who found clearly increasing concentrations of chloride in surface waters with proximity to the Trøndelag coast of Norway, with $>16 \mathrm{mg} / \mathrm{L}$ in the coastal strip.

The nearest rainfall stations monitoring precipitation chemistry are:

- Goonhilly Down, mainland Cornwall, UK, located around $5 \mathrm{~km}$ from the coast and $80 \mathrm{~km}$ east of Scilly (Conolly et al. 2010; Cape et al. 2014). This station typically exhibits around $10 \mathrm{mg} / \mathrm{L}$ chloride in rainfall, but with peaks of over $30 \mathrm{mg} / \mathrm{L}$ and higher values during the winter season.

- Birkenes, Norway, located c. $19 \mathrm{~km}$ from the coast, some $130 \mathrm{~km}$ east of Egersund and $170 \mathrm{~km}$ WSW of Hvaler (Aas and Hjellbrekke 2006). This station exhibited on average c. $2-3 \mathrm{mg} / \mathrm{L}$ chloride in precipitation in 2006 , but with peaks of over $30 \mathrm{mg} / \mathrm{L}$.

Given that it is widely recognised that (a) chloride concentrations in precipitation increase dramatically within $4 \mathrm{~km}$ of the coast, (b) salts in rainfall are upconcentrated by several multiples during processes of evapotranspiration on vegetation and in soils (up to three-fold in Wales; Neal and Kirchner 2000), and (c) they are augmented by dissolution of dry salt fallout; the chloride concentrations observed in Fig. 3 are believed to be consistent with marine derivation.

In Fig. 3, it should be noted that the Scilly waters exhibit an $\mathrm{Na} / \mathrm{Cl}$ ratio similar to sea water and generally negligible non-marine sodium (i.e. little evidence of feldspar weathering). The Scilly waters are all of $\mathrm{Na}-\mathrm{Cl}$ type. It should be noted that one of the Scilly samples was from a coastal borehole specifically abstracting saline groundwater for desalination. The groundwater is thus effectively infiltrated ocean water $\left(\mathrm{Cl}^{-}=\right.$c. $\left.20 \mathrm{~g} / \mathrm{L}, \mathrm{Na}=11 \mathrm{~g} / \mathrm{L}\right)$. The Norwegian waters, on the other hand, exhibit an $\mathrm{Na} / \mathrm{Cl}>1$ and significant nonmarine (presumed lithological) sodium.

\section{Groundwater chemistry: other (non-marine) aspects}

The Norwegian waters typically had a circum-neutral or (especially in Egersund area) somewhat alkaline $\mathrm{pH}$ and a moderate alkalinity in the range 1.5 to $6.4 \mathrm{meq} / \mathrm{L}$. The Scilly waters were considerably less hydrochemically mature, with $\mathrm{pH}$ values mostly $<6.5$ and alkalinities mostly $<1 \mathrm{meq} / \mathrm{L}$. Scilly groundwaters were also characterised by elevated chloride (location in open Atlantic), generally elevated nitrate (median $51 \mathrm{mg} / \mathrm{L}$ as $\mathrm{NO}_{3}^{-}$) and potassium (several tens to over $100 \mathrm{mg} / \mathrm{L}$, presumed to be related to leaching from agriculture).

The Norwegian waters were characterised by rather modest calcium concentrations $(<30 \mathrm{mg} / \mathrm{L}$; Fig. 4), low calcium/alkalinity meq ratios (less than unity), very high $\mathrm{Na} / \mathrm{Ca}$ ratios and high non-marine sodium concentrations. Of the Norwegian waters, those from Hvaler-Iddefjord typically exhibited the higher alkalinities, silicon concentrations and non-marine sodium excesses, indicating a greater degree of hydrochemical maturity and silicate hydrolysis. The Hvaler-Iddefjord waters are all of $\mathrm{Na}-\mathrm{HCO}_{3}$ type (or, in one case, $\mathrm{Na}-\mathrm{Cl}-\mathrm{HCO}_{3}$ ), while the Egersund waters are either $\mathrm{Na}-\mathrm{HCO}_{3}$ or $\mathrm{Mg}-(\mathrm{Ca}-\mathrm{Na})-\mathrm{HCO}_{3}$ type.

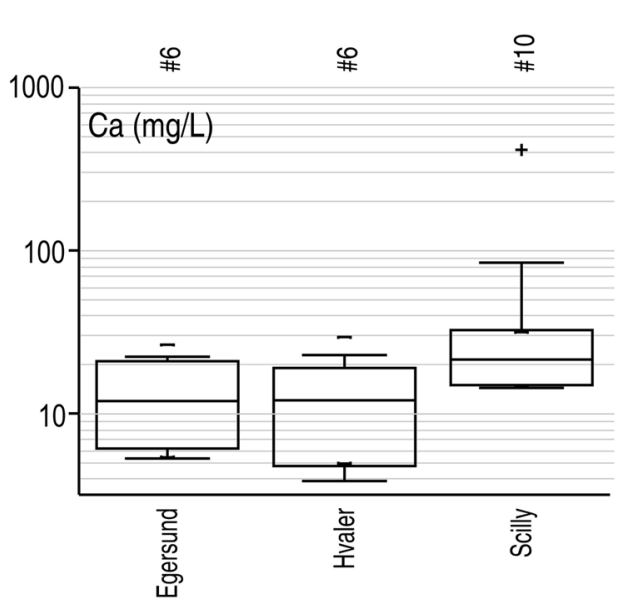

Fig. 4 Boxplots comparing (left) concentrations of calcium in groundwater from the three study areas; (centre) the calcium/alkalinity ratio in $\mathrm{meq} / \mathrm{L}$ and (right) the TDIC and total alkalinity (t-alkalinity) contents of the groundwaters (the single high TDIC value of
$59 \mathrm{mmol} / \mathrm{L}$ is from the coastal saline borehole discussed in the text). The high calcium/alkalinity ratios at Scilly are partly ascribable to the strong influence of marine salts on the groundwater (sea water has a Ca/alkalinity meq ratio of c. 8.6-Dickson and Goyet 1994) 
There was little evidence of significant depletion in sulphate due to sulphate reduction (Fig. 3) -indeed a slight non-marine sulphate excess was observed in most samples (with a median non-marine sulphate concentration of $0.2-0.3 \mathrm{meq} / \mathrm{L}$ in all three study areas), potentially ascribable to industrial sulphur oxide dissolution in recharge water, or to oxidative dissolution of geological sulphide minerals. The degree of marine influence can be seen in Fig. 5, where the groundwater sulphate $\delta^{34} \mathrm{~S}$ signature is plotted against the sulphate/chloride meq ratio. The marine-influenced (e.g. Scilly) waters plot to the top left, close to standard ocean water. Where excess sulphate is present, the $\delta^{34} \mathrm{~S}$ decreases to values around 0\%o in Egersund and to negative values in Hvaler-Iddefjord Granite. This decrease reflects an increased component of non-marine sulphate, e.g. industrial sulphur dioxide entrained in rainfall recharge or from oxidation of bedrock sulphides (Krouse and Mayer 2000; Taylor et al. 1984). Only one sample exhibits a sulphate deficit (relative to sea-water ionic ratios) of $6.1 \mathrm{meq} / \mathrm{L}$-namely, the highly saline borehole on Scilly (infiltrating marine water)—possibly indicating a modest degree of sulphate reduction.

From the known pH-dependent chemistry of the carbonate system (Mook 2000), it is reasonable to assume that, at $\mathrm{pH}>7$ (Norwegian groundwater samples) the $\mathrm{CO}_{2}$ dissolved in recharge water has reacted with basic mineral phases and that the total dissolved inorganic carbon (TDIC) is largely in the form of $\mathrm{HCO}_{3}^{-}$(alkalinity). For the Scilly samples, with their low $\mathrm{pH}$ values, this is not the case and TDIC was independently determined on the Scilly groundwaters. In fact, typical TDICs of $18-34 \mathrm{mmol} / \mathrm{L}$ were found (Fig. 4)-implying that most of the inorganic carbon found in the Scilly groundwaters is still in the form of unreacted carbonic acid $\left(\mathrm{H}_{2} \mathrm{O}+\mathrm{CO}_{2}=\mathrm{H}_{2} \mathrm{CO}_{3}\right)$ and very little (typically $<1 \mathrm{mmol} / \mathrm{L}$ ) has reacted with mineral phases to form $\mathrm{HCO}_{3}{ }^{-}$. The ratios of TDIC to alkalinity approximately correspond with those theoretically predicted at $\mathrm{pH}$ values of around 5.5 (Mook 2000).

\section{Vegetation, soils and soil gas}

The three study areas all show very similar ${ }^{13} \mathrm{C}$ signatures in vegetation, irrespective of species sampled: the bulk of the determinations are in the range $\delta^{13} \mathrm{C}=-27$ to $-30 \%$ o (Fig. 6).

The $\delta^{13} \mathrm{C}$ signatures of the organic component of the soils $(-30$ to $-26 \%$ ) fall within the same interval as the vegetation samples (Fig. 6).

The carbonate content of soils was determined only on samples from Scilly and contents ranging from $<0.001$ to $0.01 \%$ were found, with one sample of beach soil containing just over $0.4 \%$ (Fig. 7). Carbon isotope analysis was possible of two samples of inorganic soil carbonate (the high-carbonate Scilly beach soil, and a sample of pedogenic carbonate extracted from another Scilly soil sample), returning $\delta^{13} \mathrm{C}$ signatures of +2.1 and $-15.2 \%$ respectively (Fig. 6).

The marine shell sand occurring in the shallow subsurface at one location in Hvaler returned a marine inorganic carbonate signature close to zero.

Significant differences arise between the $\delta^{13} \mathrm{C}$ analyses of soil gas, however, with the soils of Scilly returning the lightest signatures, typically in the range -30 to $-26 \%$; i.e. very similar to soils. The soil gas samples from Egersund are the heaviest, typically in the range -17 to $-12 \%$ (for both Studies 1 and 2). The soil gas samples
Fig. 5 Groundwater sulphate $\delta^{34} \mathrm{~S}$, plotted against $\mathrm{SO}_{4}=$ / $\mathrm{Cl}^{-}$meq ratio for the sampled groundwaters. Typical ocean water has $\delta^{34} \mathrm{~S}=$ c. $21 \%$ (Mayer 2007; Rees et al. 1978) and $\mathrm{SO}_{4}=/ \mathrm{Cl}^{-}$meq ratio $=0.103$ (Dickson and Goyet 1994). Precipitation at Birkenes, southern Norway, has a typical $\mathrm{SO}_{4}=/ \mathrm{Cl}^{-}$meq ratio around 0.45 in 2005/2006 (Aas et al. 2006, 2007), while anthropogenic sulphate in the precipitation of the northern hemisphere usually ranges from -3 to $+9 \%$ o (Krouse and Mayer 2000)

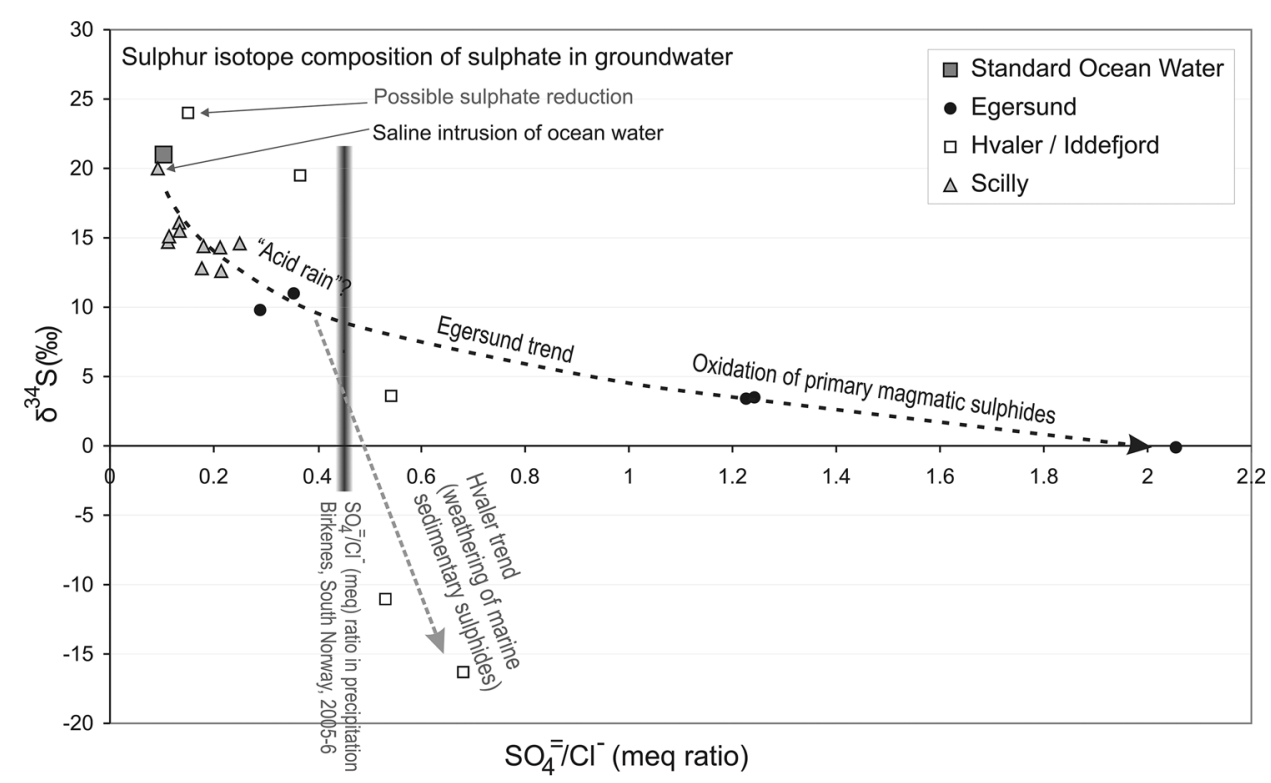


from Hvaler-Iddefjord exhibit a large range, intermediate between Scilly and Egersund.

\section{Rock}

Samples of anorthosite/granite bedrock were taken from all three study areas. Samples were of surface outcrops, which (because of the subaerial weathering histories) would be expected to be "fresher" and less weathered in Norway than in the Scilly Isles. Contents of carbonate were typically in the range $<0.001$ to $0.02 \%$, with somewhat higher contents being found in the Egersund area than in the Isles of Scilly (in line with expectations from the hypotheses of Banks et al. 1997, 1998). A few Norwegian samples exhibited higher carbonate contents in the range $0.07-0.12 \%$ (Fig. 7).

$\delta^{13} \mathrm{C}$ compositions of bedrock carbonates were in the range -13 to $-3 \%$ in the Norwegian samples, with heavier compositions recorded from the Scilly granites, in the range +0.1 to $-1.9 \%$ o (Fig. 6)

\section{Groundwater}

The $\delta^{13} \mathrm{C}$ determinations of the TDIC in the bedrock groundwater also exhibit significant differences between the three areas. In this context, it should be remembered that:

- in the Norwegian (high $\mathrm{pH}$ ) samples, the TDIC is primarily composed of $\mathrm{HCO}_{3}{ }^{-}$and (in the highest $\mathrm{pH}$ samples) $\mathrm{CO}_{3}=$. In other words, assuming a closed system with respect to $\mathrm{CO}_{2}$, the $\mathrm{CO}_{2}$ in the recharge water has almost completely reacted with basic mineral phases.

- in the lower pH Scilly groundwaters, the TDIC is primarily composed of unreacted $\left(\mathrm{CO}_{2}+\mathrm{H}_{2} \mathrm{CO}_{3}\right)$, with only a modest portion having reacted to form $\mathrm{HCO}_{3}{ }^{-}$.

The Egersund groundwaters predominantly exhibit heavy $\delta^{13} \mathrm{C}$ signatures in the range -14 to $-20 \%$ (Fig. 6), while those from Hvaler-Iddefjord Granite are not dissimilar, clustering around $-18 \%$. The Scilly groundwaters, on the other hand, exhibit groundwater $\delta^{13} \mathrm{C}$ signatures of -22 to $-26 \%$. A single groundwater sample from Scilly returned a $\delta^{13} \mathrm{C}$ of $-4.9 \%$ : this was from the coastal borehole specifically abstracting saline groundwater for desalination. The groundwater is thus largely effectively infiltrated ocean water $\left(\mathrm{Cl}^{-}=\right.$c. $\left.20 \mathrm{~g} / \mathrm{L}\right)$ and is thus heavily influenced by the marine $\delta^{13} \mathrm{C}$ (nominally $0 \%$ ).

\section{Discussion}

The vegetation and soil $\delta^{13} \mathrm{C}$ signatures are unsurprising. The soil gas signatures do, however, show significant differences, both from each other and from their parent soils.
The Scilly soil gas has a very similar signature to its parent soils, suggesting either a high soil $\mathrm{CO}_{2}$ production rate, or a low rate of soil diffusion (low permeability, deep samples) or both. All the Egersund soil gas samples from Studies 1 and 2 (Fig. 8) have a $\delta^{13} \mathrm{C}$ signature significantly heavier than the soil's organic carbon $\delta^{13} \mathrm{C}$ (and much greater than the "ideal" $+4.4 \%$ relative fractionation suggested by Cerling et al. 1991, see above). The "heavy" Egersund soil gas signature could potentially be related to a low soil $\mathrm{CO}_{2}$ production rate or to the fact that the Egersund soil profiles and superficial cover tend to be rather thin, leading to enhanced diffusion of light ${ }^{12} \mathrm{C}$ and/or mixing with atmospheric $\mathrm{CO}_{2}$. The Hvaler-Iddefjord granite soil gas samples range from having a similar signature to the soils to significantly heavier. The results for Hvaler-Iddefjord are study-dependent, those from Study 1 being significantly heavier than those from Study 2 (Fig. 8), possibly reflecting the different methodologies being used (though no effect was seen in the Egersund sampling). This effect could be related the possibility that, because of generally wet conditions during Study 1, well-drained, higher permeability soils were preferentially sampled-i.e. soils permitting diffusive loss of ${ }^{12} \mathrm{C}$. Study 2 was dry enough to permit the sampling of at least one soil from near a wetland area, returning the isotopically lightest soil gas sample from Hvaler-Iddefjord; one may speculate whether there may here have been a contribution from oxidation of isotopically light methane.

With regard to the granite/anorthosite rocks, the observed wide range in rock carbonate content and isotopic signature is perhaps unsurprising, given the differences in weathering history, the difficulties in representative sampling and the wide variety of potential mechanisms for genesis of calcite within the rock matrix or along fractures of different generations. Future studies should aim to obtain a more representative host rock data set.

To interpret the groundwaters, the ${ }^{13} \mathrm{C}$ isotopic signatures of the TDIC content have been plotted in Fig. 9, firstly against $\mathrm{pH}$ and secondly against alkalinity. These diagrams also show the theoretical idealised evolutionary trajectories of a closed silicate weathering system (vertical arrows in both cases, where the soil gas signature is essentially preserved in the groundwater TDIC), a closed carbonate weathering system and an open system (irrespective of whether it is silicate or carbonate weathering), for each of three soil gas compositions: $-26 \%$ o $-21 \%$ and $-16 \%$ o (resulting in dissolved $\mathrm{CO}_{2}$ isotopic signatures of $-27.1,-22.1$ and $-17.1 \%$, due to the $-1.1 \%$ fractionation on dissolution of $\mathrm{CO}_{2}$ gas-Table 2). In the case of the alkalinity plot, the evolution also depends on the initial soil gas $\mathrm{PCO}_{2}$ : the diagram shows curves for $10^{-1.5} \mathrm{~atm}$ (the maximum value observed by Banks and Frengstad 2006), $10^{-2.0}$ and $10^{-2.5} \mathrm{~atm}$.

The Scilly groundwater TDIC shows a very light $\delta^{13} \mathrm{C}$ signature, similar to both soil and soil gas. This is entirely 


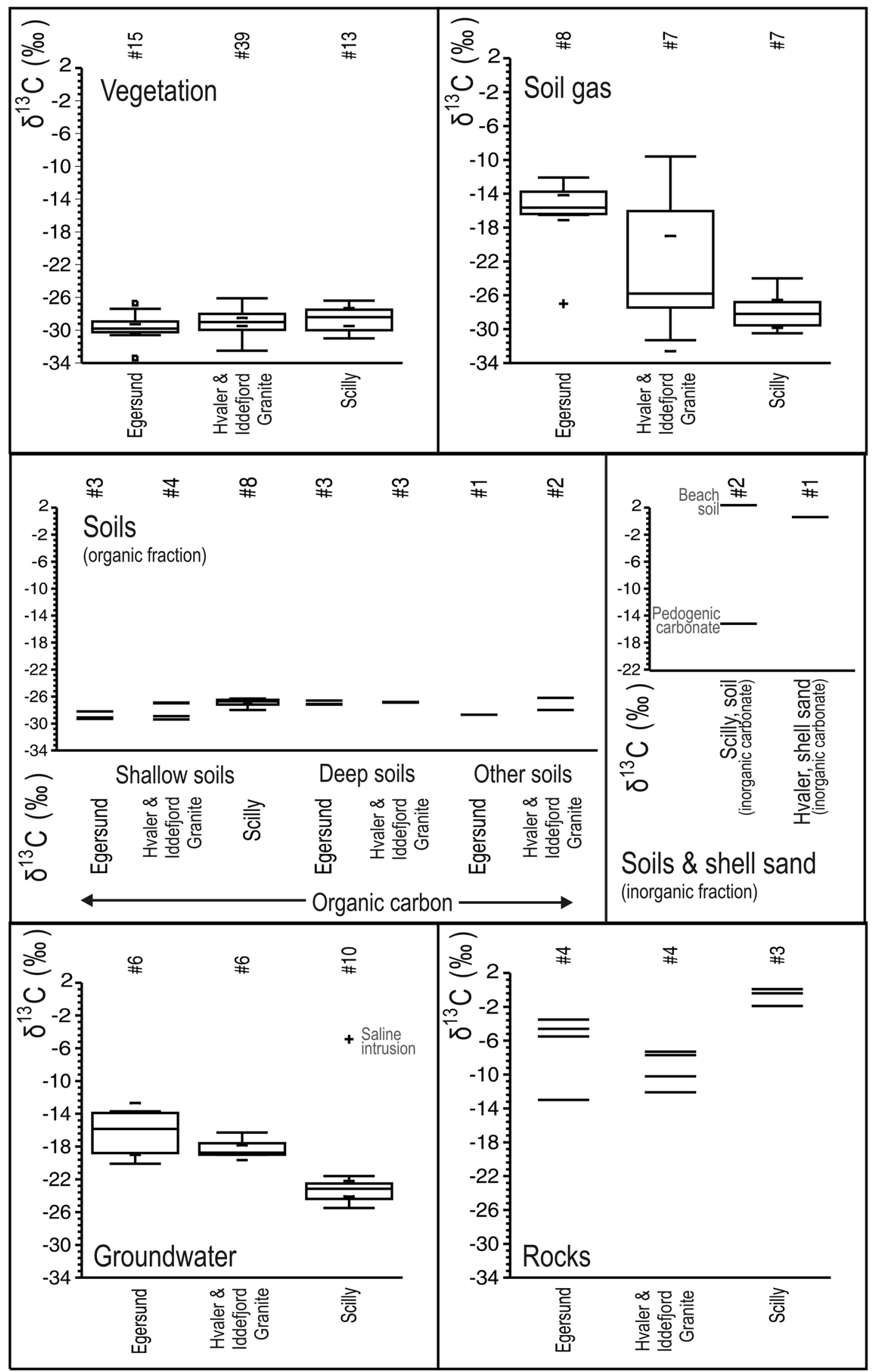


4Fig. 6 Boxplots comparing $\delta^{13} \mathrm{C}$ signatures in the three study areas for six different environmental media (vegetation, soils-organic fraction, soils and shell sand-inorganic fraction, soil gas, rocks and groundwater). \# = sample number for each subset

consistent with the expectation that the TDIC largely comprises dissolved $\mathrm{CO}_{2}$ in these low $\mathrm{pH}$ waters, only a small fraction having reacted with basic aquifer minerals to raise $\mathrm{pH}$ and release bicarbonate alkalinity. The results (Fig. 9) are all consistent with either open system carbonate or silicate weathering, with a soil gas $\delta^{13} \mathrm{C}$ of $-26 \%$, or closed silicate weathering with a slightly lower initial soil gas $\delta^{13} \mathrm{C}$ of -21 to $-25 \%$. Given that the actual soil gas determinations were typically -26 to $-30 \%$, the former is the more likely. Thus, although the results are entirely self-consistent, they do not allow us to distinguish between Models A (carbonate) and B (silicate weathering). One outlying point is seen on both diagrams in Fig. 9-the highly saline groundwater from Scilly, which is essentially intruding ocean water and whose $\delta^{13} \mathrm{C}$ signature is strongly influenced by the marine value.

The Hvaler-Iddefjord granite groundwater $\delta^{13} \mathrm{C}$ signatures are all very similar at around -17 to $-19 \%$. While vegetation/soil signatures were typically -30 to $-27 \%$, there was a wide spread of $\delta^{13} \mathrm{C}$ in the soil gas determinations themselves, ranging from similar to the soil to similar to the groundwater. In Fig. 9, the alkalinity results all fall within the "open $\mathrm{CO}_{2}$ " weathering field, consistent with a soil gas of $\delta^{13} \mathrm{C}=$ c. $-26 \%$, and $\mathrm{PCO}_{2}=10^{-2}$ to $10^{-1.5} \mathrm{~atm}$. On the other hand, the results would be equally consistent with a closed silicate weathering system, commencing with a soil gas composition of -16 to $-19 \%$ (which is still consistent with the field soil gas results). The $\mathrm{pH}$ results plot close to, but mostly slightly to the left of the $-26 \%$ o "open $\mathrm{CO}_{2}$ weathering" curve, implying either a somewhat isotopically lighter soil gas, or a component of closed silicate weathering. More significantly, the high $\mathrm{pH}$ values would be difficult to explain within an open $\mathrm{CO}_{2}$ evolutionary pathway, where the presence of a permanent reservoir of $\mathrm{CO}_{2}$ would keep pH values depressed (Fig. 10). On balance, therefore, the Hvaler-Iddefjord results suggest that some degree of closed system silicate weathering (Model B) has been important-at least during the later stages of evolution of the higher $\mathrm{pH}$ waters.

In Egersund, both Studies 1 and 2 result in a relatively narrow range of soil gas $\delta^{13} \mathrm{C}$ determinations of around -14 to $-16 \%$ - somewhat heavier than might have been expected. Groundwater TDIC exhibits a generally similar (though broader) signature $(-14$ to $-20 \%$ ). Taken at face value, this similarity is consistent with a closed system silicate hydrolysis (Model B) evolutionary pathway. In Fig. 9 (top), the theoretical dependences of TDIC $\delta^{13} \mathrm{C}$ on $\mathrm{pH}$ for closed silicate (arrows), closed carbonate (dashed lines) and open carbonate or silicate systems are shown for aquifer carbonate $\delta^{13} \mathrm{C}$ of $0 \%$ and soil gas $\left(\mathrm{CO}_{2 \text { (gas) }}\right) \delta^{13} \mathrm{C}$ of $-26 \%$, $-21 \%$ and $-16 \%$. The $\mathrm{pH}$ values at which calcite saturation is achieved for $\mathrm{PCO}_{2}=10^{-2.5}$ to $10^{-1.5} \mathrm{~atm}$. are shown as shaded zones for closed (pH c. 7.6-9.1) and open (pH c. 7-7.6) carbonate systems, respectively. Figure 9 (lower part), the theoretical dependences of TDIC $\delta^{13} \mathrm{C}$ on $\mathrm{pH}$ for closed silicate (vertical arrows), closed carbonate (lower triangular fields) and open carbonate or silicate systems (tall triangular field) are shown for aquifer carbonate $\delta^{13} \mathrm{C}$ of $0 \%$ and soil gas $\delta^{13} \mathrm{C}$ of $-26 \%$, $-21 \%$ and $-16 \%$. Within each open system and closed carbonate system field, three evolutionary lines are shown, corresponding with $\mathrm{pCO}_{2}=10^{-2.5}, 10^{-2}$ and $10^{-1.5} \mathrm{~atm}$. In Fig. 9, some of the Egersund samples fall on open system evolutionary trajectories, starting with soil gas $\mathrm{CO}_{2} \delta^{13} \mathrm{C}$ in the range -21 to $-26 \%$, while two others (at least on the $\mathrm{pH}$ diagram) fall to the left of the marked curves, suggesting even lighter soil gas $\mathrm{CO}_{2} \delta^{13} \mathrm{C}$. Such values are incompatible with the soil gas determinations recorded in the field studies. As with the Hvaler-Iddefjord samples, the high $\mathrm{pH}$ values of some of the samples would also appear incompatible with a wholly "open $\mathrm{CO}_{2}$ " weathering pathway (Fig. 10).

On balance, therefore, the combination of $\mathrm{pH}$, alkalinity and TDIC $\delta^{13} \mathrm{C}$ groundwater analyses is strongly suggestive that silicate weathering, partially in a system closed with respect to $\mathrm{CO}_{2}$, is important in the evolution of Norwegian bedrock groundwater chemistry, as well as open weathering pathways. However, $\delta^{13} \mathrm{C}$ results have not proven to be, at least in this study, an unambiguous tool for distinguishing between carbonate and silicate weathering, largely because the ideal "open $\mathrm{CO}_{2}$ " pathways for these are essentially identical. Moreover, Banks and Frengstad (2006) point out, in their study of groundwater chemical evolution in the Egersund anorthosites, that these hypothetical pure open or closed silicate or carbonate weathering pathways are too simplistic. Real groundwater evolutionary pathways are likely to include hybrid (and intermediate) mechanisms: for example, they argue that some degree of openness (with respect to $\mathrm{CO}_{2}$ ) is necessary to evolve the rather high alkalinities and dissolved solute concentrations observed in many Norwegian samples, while some degree of closure is required to generate the relatively high $\mathrm{pH}$ values of some samples (Fig. 10).

One of the issues revealed in this study has been the observation, in the case of the Norwegian sites, that the soil gas is often significantly isotopically heavier than the parent soil materials. The low sample density and lack of depth variation and seasonal variation in soil gas sampling was a major hindrance to interpreting results. There also remains the potentially awkward question of whether the soil gas extraction method employed adequately represents the soil gas that dissolves in recharging groundwater to form carbonic acid-i.e. the main source of acidity for 
Fig. 7 Boxplots comparing soil and rock carbonate contents in the three study areas
Fig. 8 Boxplots illustrating the evolution of $\delta^{13} \mathrm{C}$ signatures between different media in the three different study areas. For clarification, the four left-hand columns (vegetation, shallow, deep and other soil) all refer to analyses of the organic carbon fraction. The data from the Scilly Isles are all from Study 3
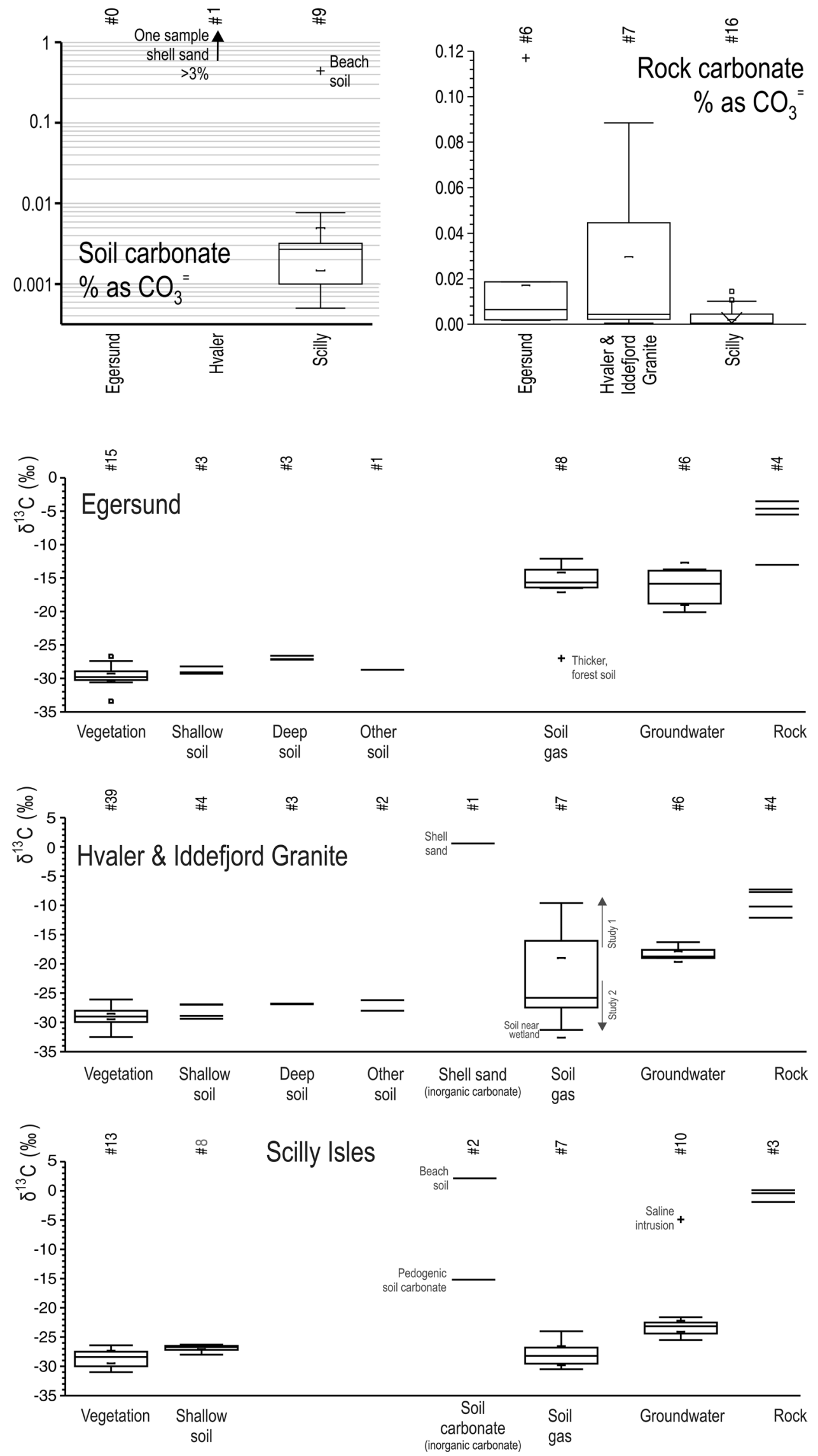
Fig. 9 Plot of (top) field $\mathrm{pH}$ and (bottom) field alkalinity against groundwater TDIC $\delta^{13} \mathrm{C}$ signatures for the three study areas. Theoretical dependences of TDIC $\delta^{13} \mathrm{C}$ on (top) $\mathrm{pH}$ and (bottom) alkalinity for closed silicate (arrows), closed carbonate and open carbonate or silicate systems are shown for various soil gas $\delta^{13} \mathrm{C}$ and an aquifer carbonate $\delta^{13} \mathrm{C}$ of $0 \%$. Chemical speciation is calculated at $10{ }^{\circ} \mathrm{C}$ using the model PHREEQC Interactive (Parkhurst and Appelo 1999), while isotopic composition is calculated using the methodology of Deines et al. (1974) and the fractionation constants provided by Clark and Fritz (1997, Table 2). See text for further explanation
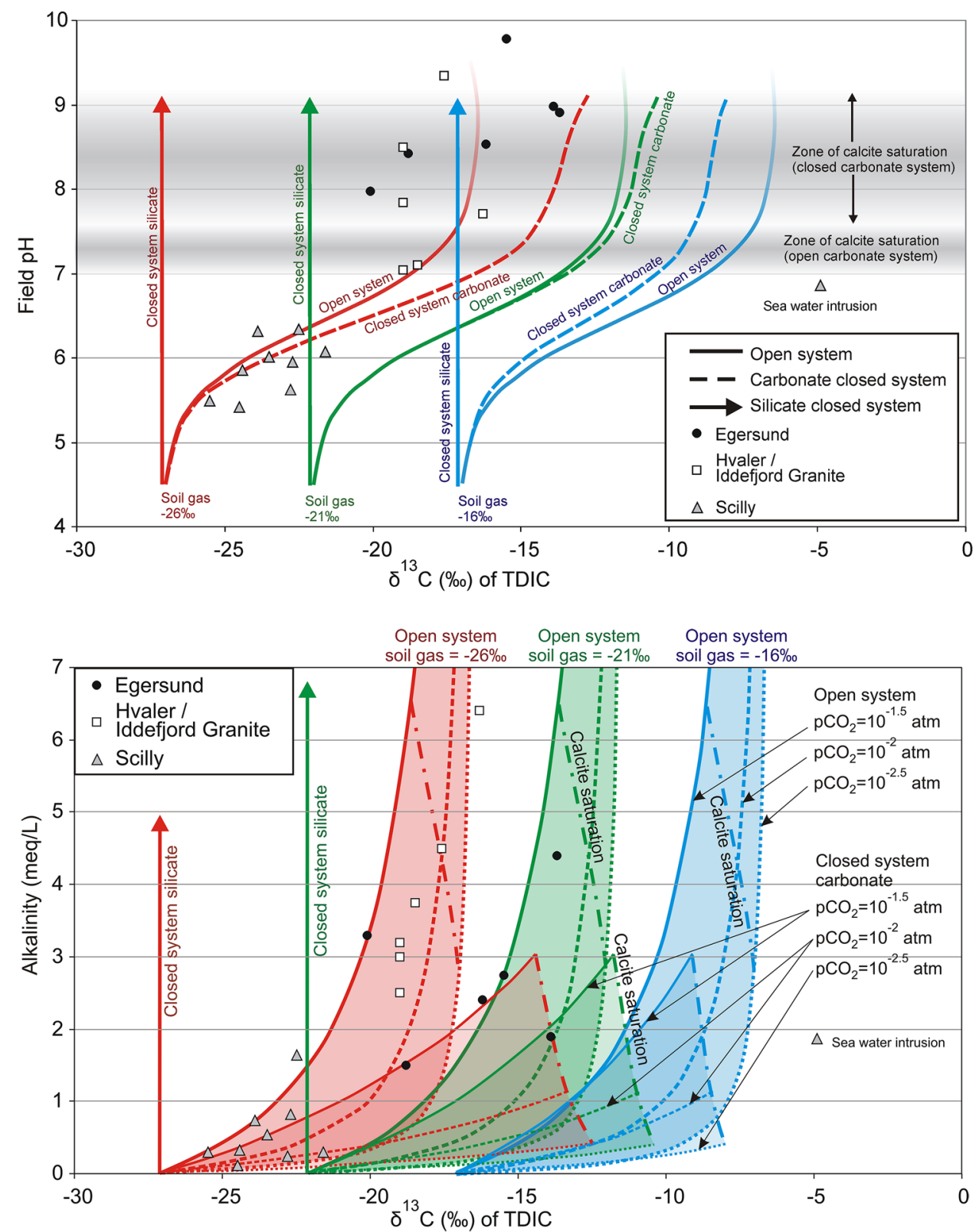

carbonate and silicate hydrolysis. The sampling method employed in these studies (suction via a steel tube) may favour high permeability and porosity volumes of the soil, whereas intimate soil gas-water-rock interaction may favour small pore spaces with low permeability and high surface area. Samples of soil gas in Norway were taken in the summer, yet much of the recharge occurs in the autumn through to spring snow-melt (at least in low-lying areas where ground is not frozen in the winter), when the soil $\mathrm{CO}_{2}$ concentrations and $\delta^{13} \mathrm{C}$ may be significantly different. Future studies should focus on more representative and rigorous $\delta^{13} \mathrm{C}$ sampling of soil gas and of unsaturated zone soil water (recharge water), both in space and time, to better constrain the results.

\section{Conclusion}

Banks and Frengstad (2006) pointed out that many of the hydrochemical evolutionary features of crystalline bedrock 
Fig. 10 Field-derived $\mathrm{pH}$ and alkalinity data from the three study areas, plotted on theoretical evolutionary trajectories (calculated using PHREEQC at $10{ }^{\circ} \mathrm{C}$-Parkhurst and Appelo 1999) for open $\mathrm{CO}_{2}$ weathering, closed silicate weathering and closed calcium carbonate weathering systems. The calcite saturation curve only applies to the calcium carbonate weathering trajectories; for silicates, the point of calcite saturation will depend on the cationic composition of the silicates and the solution

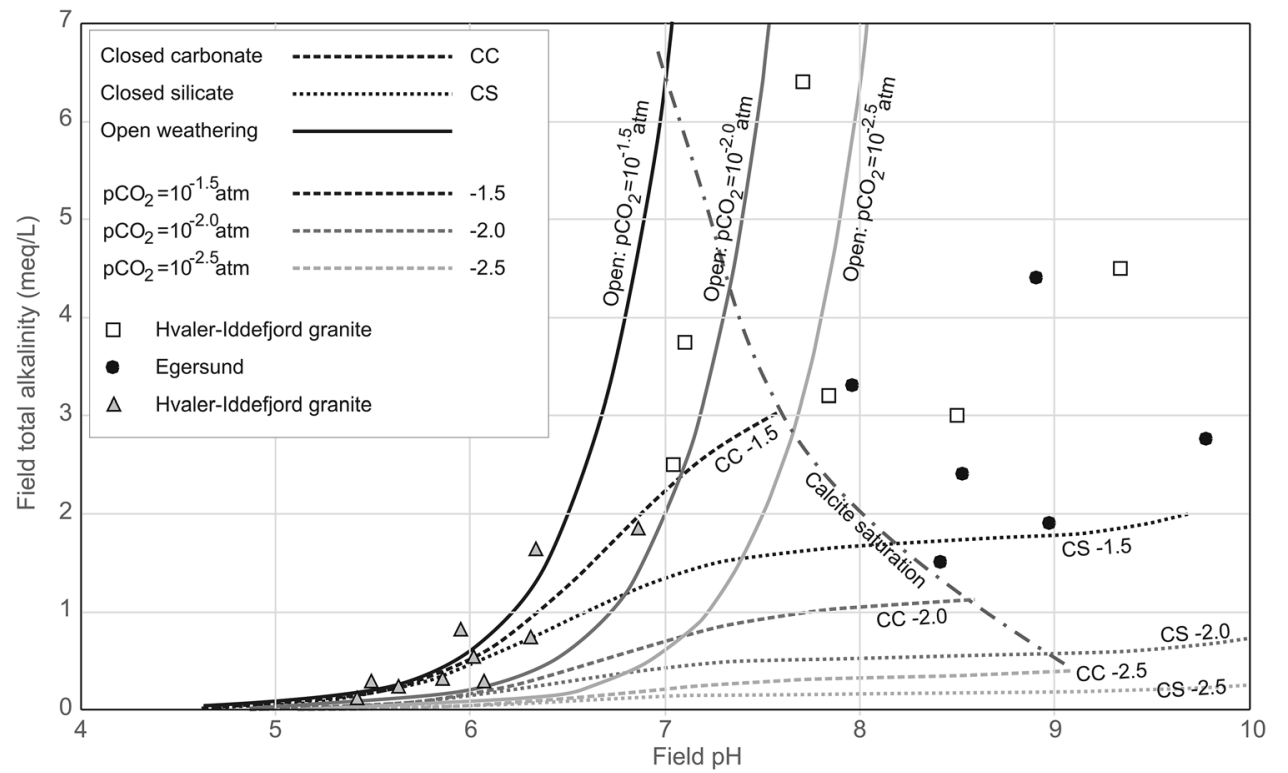

groundwater can be explained by hydrolysis of aluminosilicate mineral phases (so-called Model B-equations 2, 3 ). They contrasted this with an alternative model whereby alkalinity and base cations are generated by kinetically rapid hydrolysis of carbonate minerals in superficial deposits or along fracture surfaces, followed by ion exchange to increase sodium concentrations, deplete calcium and allow further accumulation of alkalinity, resulting in an alkaline sodium bicarbonate water type (so-called Model A-equations 1a, 1b). Several authors, including Banks and Frengstad (2006) and Schulte et al. (2011), also hypothesised that an examination of ${ }^{13} \mathrm{C}$ in groundwater TDIC may be able to distinguish between the two models.

This question is of interest for pure academic reasonsrather few studies have questioned the ultimate source of TDIC in groundwater in crystalline bedrock aquifers or have characterised ${ }^{13} \mathrm{C}$ signatures in their groundwaters. It also has a practical interest-consumption of $\mathrm{CO}_{2}$ by mineral hydrolysis is a significant global $\mathrm{CO}_{2}$ sink (Brady 1991; Liu and Zhao 2000; Probst et al. 1998; Gaillardet et al. 1999; Amiotte-Suchet et al. 2003; Beaulieu et al. 2012) and large areas of the globe are underlain by crystalline rock terrain. The predominance of Model A in generating groundwater alkalinity potentially may lead to no permanent net $\mathrm{CO}_{2}$ sink, as $\mathrm{CO}_{2}$ can ultimately be re-released (Eq. 4) to the atmosphere. Model B potentially represents a $50 \%$ net sink for $\mathrm{CO}_{2}$.

This study has examined the evolution of the ${ }^{13} \mathrm{C}$ signature from vegetation, through soil, soil gas and rock carbonate, to groundwater TDIC at several discrete localities within two Norwegian and one British crystalline rock terrains. In the first study area, the granitic Scilly Isles of south-west England, the groundwaters were very immature hydrochemically and most of the groundwater TDIC was in the form of carbonic acid, reflecting the soil gas ${ }^{13} \mathrm{C}$ isotopic signature.

In the Iddefjord Granite study area of south-east Norway, a wide range of soil gas $\delta^{13} \mathrm{C}$ was found. However, groundwaters typically exhibited $\delta^{13} \mathrm{C}$ of around $-18 \%$, irrespective of alkalinity. The groundwater $\delta^{13} \mathrm{C}$ signature could be construed as compatible with either closed system (with respect to $\mathrm{CO}_{2}$ ) silicate weathering or open system silicate or carbonate weathering. The combination of high $\mathrm{pH}$ and light $\delta^{13} \mathrm{C}$ in some samples does, however, suggest at least a component of closed system silicate weathering.

In the Egersund study area of south-west Norway, the soil gases were unexpectedly isotopically heavy, typically ranging from -12 to $-17 \%$. Groundwaters also exhibited a range of -14 to $-20 \%$, which similarity also tentatively offers support for at least a component of closed system silicate weathering.

The three studies reported in this paper have demonstrated that:

- $\delta^{13} \mathrm{C}$ analyses are not a simple technique to distinguish between silicate and carbonate weathering pathways, partially because ideally "open" (with respect to $\mathrm{CO}_{2}$ ) evolutionary trajectories are essentially identical for silicate and carbonate weathering.

- The notion of a clear distinction between "closed" and "open" (with respect to $\mathrm{CO}_{2}$ ) and between carbonate and silicate weathering pathways is conceptually flawed. Accumulating evidence from Norwegian crystalline bedrock aquifers strongly suggests that hybrid or intermediate pathways are more likely (and arguably necessary to 
explain some combinations of features, such as both high $\mathrm{pH}$ and high alkalinity).

To achieve a better understanding of ${ }^{13} \mathrm{C}$ isotope systematics in crystalline bedrock environments, more attention needs to be given to the characterisation of (1) the soil gas system's behaviour and isotopic signature throughout the seasons, (2) how carbon dioxide is solubilised and reacts in the early stages of groundwater evolution and (3) whether, and at what stage, the weathering system becomes closed with respect to $\mathrm{CO}_{2}$. In particular, in future studies:

1. A limited number of study sites in Norway should be prioritised and greater effort expended in sampling soil gas at different depths and seasons throughout the soil profile/unsaturated zone, preferably on a three-dimensional grid at each sampling locality.

2. Following soil-gas sampling, the soil profile should be excavated and the mineralogy and grain-size distribution characterised with depth.

3. Lysimeters should be installed in the unsaturated zone and/or at the drift/bedrock interface, such that recharging water can be sampled for alkalinity, $\mathrm{pH}$, isotopic signature and groundwater chemistry, in order to better constrain the isotopic signature evolution between soil gas and downward percolating recharge.

Acknowledgements The authors wish to offer grateful thanks to the anonymous reviewers whose comments enhanced our understanding of ${ }^{13} \mathrm{C}$ systematics in hard rock groundwater systems and greatly improved the content of this paper.

Open Access This article is distributed under the terms of the Creative Commons Attribution 4.0 International License (http://creativecommons.org/licenses/by/4.0/), which permits unrestricted use, distribution, and reproduction in any medium, provided you give appropriate credit to the original author(s) and the source, provide a link to the Creative Commons license, and indicate if changes were made.

\section{References}

Aas W, Hjellbrekke A (2006) EBAS 1.1 dataset for precipitation chemistry from Birkenes (NO0001R.20060101070000.20100416000000. bulk_sampler..precip.1y.1d.NO01L_bs_d_0001...nas). Electronic dataset. Norwegian Institute for Air Research (NILU), Kjeller, Norway. Available via ebas.nilu.no

Aas W, Solberg S, Berg T, Manø S, Yttri KE (2006) Overvåking av langtransportert forurenset luft og nedbør: Atmosfærisk tilførsel, 2005 [Monitoring of long-transported polluted air and precipitation: Atmospheric contribution, 2005-in Norwegian]. Norsk institutt for luftforskning (NILU) report 955/2006

Aas W, Solberg S, Manø S, Yttri KE (2007) Overvåking av langtransportert forurenset luft og nedbør: Atmosfærisk tilførsel, 2006 [Monitoring of long-transported polluted air and precipitation:
Atmospheric contribution, 2006-in Norwegian]. Norsk institutt for luftforskning (NILU) report 985/2007

Alpers CN, Dettman DL, Lohmann KC, Brabec D (1990) Stable isotopes of carbon dioxide in soil gas over massive sulfide mineralization at Crandon, Wisconsin. J Geochem Explor 38:69-86. doi:10.1016/0375-6742(90)90093-P

Amiotte-Suchet P, Probst JL, Ludwig W (2003) Worldwide distribution of continental rock lithology: implications for atmospheric/ soil $\mathrm{CO}_{2}$ uptake by continental weathering and alkalinity river transport to the oceans. Glob Biogeochem Cycles 17(2):1038. doi :10.1029/2002GB001891

Appelo CAJ, Postma D (2005) Geochemistry, groundwater and pollution, 2nd edn. AA Balkema, Leiden

Ashwal LD (1993) Anorthosites. Springer-Verlag, Berlin

Atkinson T (1977) Carbon dioxide in the atmosphere of the unsaturated zone: an important control of groundwater hardness in limestones. J Hydrol 35:111-123. doi:10.1016/0022-1694(77)90080-4

Banks D, Sæther OM, Ryghaug P, Reimann C (2001) Hydrochemical distribution patterns in stream waters, Trøndelag, central Norway. Sci Total Environ 267:1-21. doi:10.1016/S0048-9697(00)00605-7

Banks D, Frengstad B (2006) Evolution of groundwater chemical composition by plagioclase hydrolysis in Norwegian anorthosites. Geochim Cosmochim Acta 70:1337-1355. doi:10.1016/j. gca.2005.11.025

Banks D, Solbjørg ML, Rohr-Torp E (1992a) Permeability of fracture zones in a Precambrian granite. Q J Eng Geol 25:377-388. doi:10.1144/GSL.QJEG.1992.025.04.12

Banks D, Rohr-Torp E, Skarphagen H (1992b) An integrated study of a Precambrian granite aquifer, Hvaler, southeastern Norway. Norges geologiske unders $ø$ kelse Bulletin 422:47-66. http://www. ngu.no/FileArchive/NGUPublikasjoner/Bulletin422_47-66.pdf. Accessed 4th May 2017

Banks D, Rohr-Torp E, Skarphagen H (1993a) Groundwater chemistry in a Precambrian granite island aquifer, Hvaler, Southeastern Norway. In: Banks SB, Banks D (eds) Hydrogeology of hard rocks, Mem. 24th Congress of International Association of Hydrogeologists, 28th June- 2nd July 1993, Ås (Oslo), Norway. Geological Survey of Norway, Trondheim, pp 395-406

Banks D, Reimann C, Røyset O, Skarphagen H (1993b) Natural concentrations of major and trace elements in some Norwegian bedrock groundwaters. Norges geologiske unders $\varnothing$ kelse Rapport 93.126. Norges geologiske undersøkelse, Trondheim, Norway. http://www.ngu.no/upload/Publikasjoner/Rapporter/1993/93_126. pdf. Accessed 3 May 2016

Banks D, Rohr-Torp E, Skarphagen H (1994) Groundwater resources in hard rock; experiences from the Hvaler study, Southeastern Norway. Appl Hydrogeol 2(2):33-42. doi:10.1007/s100400050040

Banks D, Skarphagen H, Reimann C, Watkins D (1997) The comparative hydrochemistry of two granitic island aquifers: The Isles of Scilly, UK and the Hvaler Islands, Norway. Norges geologiske unders $\varnothing$ kelse Rapport 97.070. Norges geologiske unders $\varnothing$ kelse, Trondheim, Norway. http://www.ngu.no/upload/Publikasjoner/ Rapporter/1997/97_070.pdf. Accessed 3 May 2016

Banks D, Reimann C, Skarphagen H (1998) The comparative hydrochemistry of two granitic island aquifers: The Isles of Scilly, UK and the Hvaler Islands, Norway. Sci Total Environ 209:169-183. doi:10.1016/S0048-9697(98)80108-3

Banks D, Gundersen P, Gustafson G, Mäkelä J, Morland G (2010) Regional similarities in the distributions of well yield from crystalline rocks in Fennoscandia. Norges Geologiske Undersøkelse Bulletin 450:33-47

Barrow G, Flett JS (1906) The geology of the Isles of Scilly. Memoirs of the Geological Survey of England \& Wales, explanation of sheets 357 and 360. HMSO, London

Beaulieu E, Goddéris Y, Donnadieu Y, Labat D, Roelandt C (2012) High sensitivity of the continental-weathering carbon dioxide 
sink to future climate change. Nat Clim Change 2:346-349. doi:10.1038/nclimate1419

Bottomley DJ, Gascoyne M, Kamineni DC (1990) The geochemistry, age and origin of groundwater in a mafic pluton, East Bull lake, Ontario, Canada. Geochim Cosmochim Acta 54:993-1008. doi:10.1016/0016-7037(90)90433-L

Brady PV (1991) The effect of silicate weathering on global temperature and atmospheric $\mathrm{CO}_{2}$. J Geophys Res 96(B11):18101-18106. doi:10.1029/91JB01898

Cape JN, Smith RI, Leaver DS (2014). Cleaned UK rainfall chemistry data (1986-2011). NERC environmental information data centre. https://doi.org/10.5285/ada39609-ddec-4cbe-85c2-4fdd6bd774d7. Accessed 2 May 2017

Cerling TE (1984) The stable isotopic composition of modern soil carbonate and its relationship to climate. Earth Planet Sci Lett 71:229-240. doi:10.1016/0012-821X(84)90089-X

Cerling TE, Solomon DK, Quade J, Bowman JR (1991) On the isotopic composition of carbon in soil carbon dioxide. Geochim Cosmochim Acta 55:3403-3405. doi:10.1016/0016-7037(91)90498-T

Chen Y, Clark AH, Farrar E, Wasteneys HAHP, Hodgson MJ, Bromley AV (1993) Diachronous and independent histories of plutonism and mineralization in the Cornubian Batholith, southwest England. J Geol Soc 150(6):1183-1191. doi:10.1144/gsjgs.150.6.1183

CHESS (2017) CHESS interactive mapping service. Centre for ecology and hydrology. https://eip.ceh.ac.uk/apps/chess/. Accessed 6 May 2017

Clark HD, Fritz P (1997) Environmental isotopes in hydrogeology. CRC Press, USA, p 342

Conolly C, Lawrence H, Vincent K, Donovan B, Davies M, Colbeck C, Cape JN, Tang YS, Bealey WJ, Leaver D, Poskitt J, Beith S, Thacker S, Hockenhull K, Woods C, Simmons I, Braban CF, van Dijk N, Rowland P, Fowler D, Sutton MA (2010) AQ0616 UK eutrophying and acidifying atmospheric pollutants (UKEAP) B. Annual report 2010. AEA Technology and Centre for Ecology and Hydrology, UK

Craig H (1953) The geochemistry of the stable carbon isotopes. Geochim Cosmochim Acta 3:53-92. doi:10.1016/0016-7037(53)90001-5

Deines P, Langmuir D, Harmon RS (1974) Stable carbon isotope ratios and the existence of a gas phase in the evolution of carbonate ground waters. Geochim Cosmochim Acta 88:1147-1164. doi:10.1016/0016-7037(74)90010-6

Dickson AG, Goyet C (eds) (1994) Handbook of methods for the analysis of the various parameters of the carbon dioxide system in sea water; version 2. US Dept. of Energy, Report ORNL/CDIAC-74. Oak Ridge, USA

Dörr H, Münnich KO (1980) Carbon-14 and carbon-13 in soil $\mathrm{CO}_{2}$. Radiocarbon 22(3):909-918

Emrich K, Ehhalt DH, Vogel JC (1970) Carbon isotope fractionation during the precipitation of calcium carbonate. Earth Planet Sci Lett 8:363-371. doi:10.1016/0012-821X(70)90109-3

Eriksson E (1952) Composition of atmospheric precipitation. II: sulfur, chloride, iodine compounds; bibliography. Tellus 4(4):280-303. doi:10.1111/j.2153-3490.1952.tb01014.x

Frengstad B, Banks D (2007) Universal controls on the evolution of groundwater chemistry in crystalline bedrock: the evidence from empirical and theoretical studies. In: Krásný J, Sharp JM (eds) Groundwater in fractured rocks. Taylor \& Francis, London, pp 275-289

Frengstad B, Banks D (2000) Evolution of high-pH Na- $\mathrm{HCO}_{3}$ groundwaters in anorthosites: silicate weathering or cation exchange? In: Sililo $\mathrm{O}$ et al (eds) Groundwater: past achievements and future challenges, Proc. XXXII Congress of the International Association of Hydrogeologists, Cape Town, South Africa. Balkema, Rotterdam, pp 493-498
Frengstad B, Banks D, Siewers U (2001) The chemistry of Norwegian groundwaters: IV. The $\mathrm{pH}$-dependence of element concentrations in crystalline bedrock groundwaters. Sci Total Environ 277:101117. doi:10.1016/S0048-9697(00)00867-6

Gaillardet J, Dupré B, Louvat P, Allègre CJ (1999) Global silicate weathering and $\mathrm{CO}_{2}$ consumption rates deduced from the chemistry of large rivers. Chem Geol 159:3-30. doi:10.1016/ S0009-2541(99)00031-5

Garrels RM (1967) Genesis of some ground waters from igneous rocks. In: Abelson PH (ed) Researches in geochemistry. Wiley, New York, pp 405-420

Garrels RM, Mackenzie FT (1967) Origin of the chemical compositions of some springs and lakes. In: Stumm W (ed) Equilibrium concepts in natural water systems. Advances in chemistry series 67. American Chemical Society, Washington, DC, pp 222-242

Gascoyne M, Kamineni DC (1993) The hydrochemistry of fractured plutonic rocks in the Canadian Shield. In: Banks SB, Banks D (eds) Hydrogeology of hard rocks, Mem. 24th Congress of International Association of Hydrogeologists, 28th June-2nd July 1993, Ås (Oslo), Norway. Geological Survey of Norway, Trondheim, pp 440-449

Gillon M, Barbecot F, Gibert E, Plain C, Corcho-Alvarado JA, Massault $\mathrm{M}$ (2012) Controls on ${ }^{13} \mathrm{C}$ and ${ }^{14} \mathrm{C}$ variability in soil $\mathrm{CO}_{2}$. Geoderma 189-190:431-441. doi:10.1016/j.geoderma.2012.06.004

Hiemstra JF, Evans DJA, Scourse JD, McCarroll D, Furze MFA, Rhodes E (2006) New evidence for a grounded Irish Sea glaciation of the Isles of Scilly, UK. Quat Sci Rev 25:299-309. doi:10.1016/j. quascirev.2005.01.013

Holtedahl O (1960) The geology of Norway (2 vols). Norges geologiske unders $\varnothing$ kelse 208:1-540

HydroTeamRC (2015) ArcGIS world evapotranspiration web viewer, based on NASA's moderate resolution imaging spectroradiometer (MODIS) data set. https://www.arcgis.com/home/webmap/viewer. $\mathrm{html}$ ?webmap=6cc9c3c1c2934bacbebd94a0e9b48c49. Accessed 6 May 2017

Jones DL (1963) The accessory minerals of the Scilly Isles granites. Proc Ussher Soc 1:47-50

Kocheise R (1994) Svelleleire i undersjøiske tunneler [Swelling clay in subsea tunnels—in Norwegian]. Dr.ing. thesis no. 1994:124. Norges Tekniske Høgskole (NTH). Trondheim, Norway

Krouse HR, Mayer B (2000) Sulfur and oxygen isotopes in sulfate. Chapter 7. In: Cook P, Herczeg AL (eds) Environmental tracers in subsurface hydrology. Kluwer, Norwell, USA, pp 195-231

Leeflang KWH (1938) De chemische Samenstelling van den Neerslag in Nederland [The chemical composition of precipitation in the Netherlands-in Dutch]. Chemisch Weekblad 35:658-664

Liu Z, Zhao J (2000) Contribution of carbonate rock weathering to the atmospheric $\mathrm{CO}_{2}$ sink. Environ Geol 39:1053-1058. doi:10.1007/ s002549900072

Mayer B (2007) Assessing sources and transformations of sulphate and nitrate in the hydrosphere using isotope techniques. In: Aggarwal P, Gat J, Froehlich KFO (eds) Isotopes in the water cycle: past, present and future of a developing science. IAEA/Springer, Dordrecht, pp 67-90

Met. Office (2017) St. Mary's Heliport climate. Meteorological Office website. http://www.metoffice.gov.uk/public/weather/climate/. Accessed 6 May 2017

Mitchell GF, Orme AR (1967) The Pleistocene deposits of the Isles of Scilly. Quart J Geol Soc 123:59-92. doi:10.1144/gsjgs.123.1.0059

Mook WG (2000) Chemistry of carbonic acid in water. Chapter 9 in: Environmental isotopes in the hydrological cycle: volume 1 principles and applications. IAEA/UNESCO, Paris. pp. 86-96. http:// www-naweb.iaea.org/napc/ih/documents/global_cycle/Environmental\%20Isotopes $\% 20$ in $\% 20$ the $\% 20$ Hydrological $\% 20$ Cycle $\% 20$ Vol\%201.pdf. Accessed 9 Jul 2014 
Mook WG, Bommerson JC, Staverman WH (1974) Carbon isotope fractionation between dissolved bicarbonate and gaseous carbon dioxide. Earth Planet Sci Lett 22:169-176. doi:10.1016/0012-821X(74)90078-8

Neal C, Kirchner JW (2000) Sodium and chloride levels in rainfall, mist, streamwater and groundwater at the Plynlimon catchments, mid-Wales: inferences on hydrological and chemical controls. Hydrol Earth Syst Sci 4:295-310. doi:10.5194/hess-4-295-2000

Norges geologiske unders $\varnothing$ kelse (2014) Nasjonal løsmassedatabase [National database for unconsolidated sediments-in Norwegian]. http://geo.ngu.no/kart/losmasse. Accessed 3 Nov 2014

Norsk Klimaservicesenter (2017a) Klimaprofil Rogaland. Norsk Klimaservicesenter report, January 2017. Norwegian Centre for Climate Services (NCCS), c/o Norwegian Meteorological Institute, Oslo, Norway

Norsk Klimaservicesenter (2017b) Klimaprofil Østfold. Norsk Klimaservicesenter report, February 2017. Norwegian Centre for Climate Services (NCCS), c/o Norwegian Meteorological Institute, Oslo, Norway

Osman CW (1928) The granites of the Isles of Scilly and their relation to the Dartmoor granites. Quart J Geol Soc 84:258-289. doi:10.1144/GSL.JGS.1928.084.01-04.10

Oxaal J (1916) Norsk granitt [Norwegian granite-in Norwegian]. Norges. geologiske unders $\varnothing$ kelse 76:1-220

Parkhurst DL, Appelo CAJ (1999) User's guide to PHREEQC (Version 2) - a computer program for speciation, batch-reaction, onedimensional transport, and inverse geochemical calculations. U.S. Geological Survey Water Resources Investigations Report $99-4259$, p. 310

Pedersen S, Maaløe S (1990) The Iddefjord granite: geology and age. Norges geologiske unders $ø$ kelse Bulletin 417:55-64

Probst JL, Amiotte Suchet P, Boeglin JL, Mortatti J, Ludwig W (1998) Silicate rock weathering and atmospheric/soil $\mathrm{CO}_{2}$ consumed by major world river basins. Miner Mag 62A:1216-1217. doi:10.1180/minmag.1998.62A.2.301

Qi Y, Xu M, Wu J (2002) Temperature sensitivity of soil respiration and its effects on ecosystem carbon budget: nonlinearity begets surprises. Ecol Modell 153:131-142. doi:10.1016/ S0304-3800(01)00506-3

Ratcliffe J (1992) Scilly's archaeological heritage. Cornwall archaeological unit. Twelveheads Press, Truro

Rees CE, Jenkins WJ, Monster J (1978) The sulphur isotopic composition of ocean water sulphate. Geochim Cosmochim Acta 42:377-381. doi:10.1016/0016-7037(78)90268-5

Schärer U, Wilmart E, Duchesne JC (1996) The short duration and anorogenic character of anorthosite magmatism: $\mathrm{U}-\mathrm{Pb}$ dating of the Rogaland complex, Norway. Earth Planet Sci Lett 139:335350. doi:10.1016/0012-821X(96)00033-7
Schulte P, Van Geldern R, Freitag H, Karim A, Négrel P, PeteletGiraud E, Probst A, Probst JL, Telmer K, Veizer J, Barth JA (2011) Applications of stable water and carbon isotopes in watershed research: weathering, carbon cycling, and water balances. Earth Sci Rev 109:20-31. doi:10.1016/j.earscirev.2011.07.003

Selmer-Olsen R (1964) Alminnelig geologi og ingeniørgeologi [General geology and engineering geology-in Norwegian]. Tapir forlag, Trondheim

SMHI (2017) Årlig potentiell avdunstning medelvärde 19611990. Swedish Meteorological and Hydrological Institute (SMHI website. https://www.smhi.se/klimatdata/hydrologi/ vattenstand-2-2-338/arlig-potentiell-avdunstning-medelvarde-1961-1990-1.4098. Accessed 6 May 2017

Smith RA (1872) Air and rain: the beginnings of a chemical climatology. Longmans, Green and Co., London, p. 600

Staddon PL (2004) Carbon isotopes in functional soil ecology. Trends Ecol Evol 19:148-154. doi:10.1016/j.tree.2003.12.003

Stone M, Exley CS (1989) Geochemistry of the Isles of Scilly pluton. Proc Ussher Soc 7:152-157

Sundseth K (2009) Natura 2000 in the Boreal Region. European Commission. Environ Dir Gener. doi:10.2779/84505

Szaran J (1998) Carbon isotope fractionation between dissolved and gaseous carbon dioxide. Chem Geol 150:331-337. doi:10.1016/ S0009-2541(98)00114-4

Taylor BE, Wheeler MC, Nordstrom DK (1984) Isotope composition of sulphate in acid mine drainage as measure of bacterial oxidation. Nature 308:538-541. doi:10.1038/308538a0

Watkins DC (2000) Role of geographical information systems and groundwater modelling in water resource management for small islands: a case study from St. Martin's and St. Agnes, Isles of Scilly, UK. In: Robins NS, Misstear BDR groundwater in the Celtic regions: studies in hard rock and Quaternary hydrogeology. Geological Society of London Special Publication 182:247268. doi:10.1144/GSL.SP.2000.182.01.22

White AF, Bullen TD, Vivit DV, Schulz MS, Clow DW (1999) The role of disseminated calcite in the chemical weathering of granitoid rocks. Geochim Cosmochim Acta 63:1939-1953. doi:10.1016/ S0016-7037(99)00082-4

White AF, Schulz MS, Lowenstern JB, Vivit DV, Bullen TD (2005) The ubiquitous nature of accessory calcite in granitoid rocks: Implications for weathering, solute evolution, and petrogenesis. Geochim Cosmochim Acta 69:1455-1471. doi:10.1016/j. gca.2004.09.012 